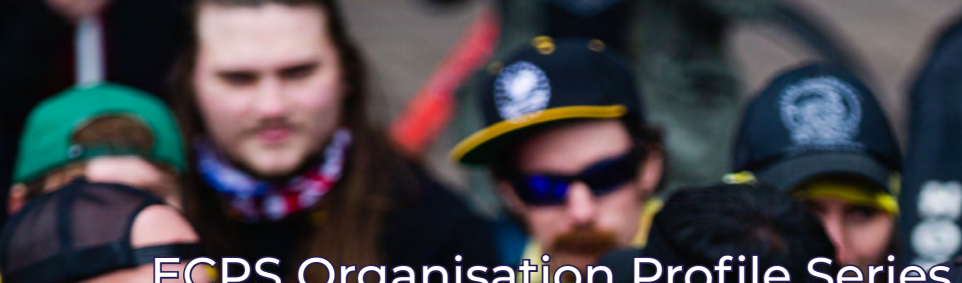

ECPS Organisation Profile Series \#1
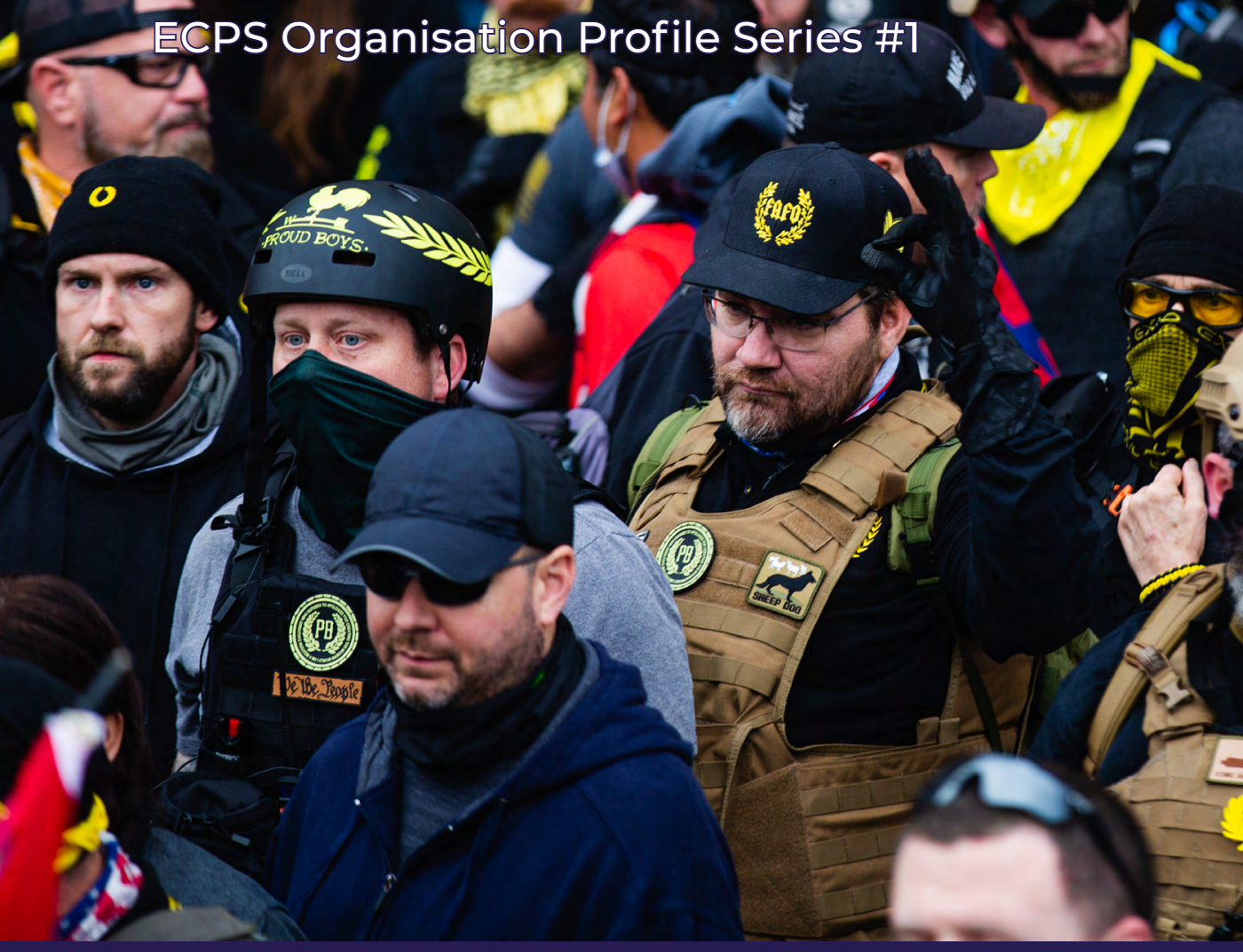

AUTHOR: Bulent Kenes

\title{
The Proud Boys: Chauvinist poster child of far-right extremism
}

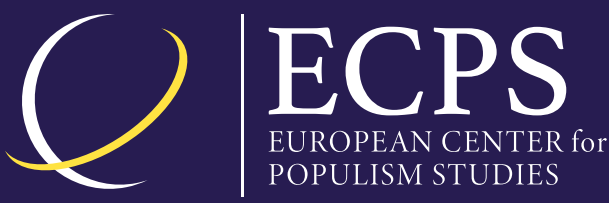




\section{The Proud Boys: \\ Chauvinist poster child of far-right extremism}

BY BULENT KENES

\section{ABSTRACT}

The Proud Boys is a far-right, anti-immigrant, all-male group who have been known to use violence against left-wing opponents. The group describes themselves as "Western chauvinists," by which they mean "men who refuse to apologise for creating the modern world". The group, which is the new face of far-right extremism, one that recruits through shared precarity and male grievances promotes and engages in political violence.

BULENT KENES is an academic and a journalist who has over 25 years of professional experience. He has managed multiple publications, both in Turkish and English.

ECPS Leader Profile Series offer analyses of political leaders and prominent public figures with populist tendencies. Unless otherwise indicated, the views expressed by the author are only attributable him and not to any institution with which they are associated.

The profile available for free downloading from the ECPS website (wwW. populismstudies.org)

(C)EPS 2021 


\section{Table of contents}

1. INTRODUCTION.

2. CULTURAL HIJACKING: REPURPOSING UHURU

8

3. A SUPREMACIST ALT-RIGHT ORGANISATION PRETENDING TO BE ALT-LITE

4. A LIBERTARIAN-FASCIST MOVEMENT THAT VENERATES HOUSEWIVES.

5. THE PROUD BOYS FOUND A SOULMATE IN DONALD TRUMP . . . . . 13

6. VIOLENCE AS A FOUNDING IDEOLOGY

7. LONGING FOR THE DAYS WHEN GIRLS WERE GIRLS AND MEN WERE MEN

8. PROUD TO BE ISLAMOPHOBIC

9. ANTISEMITISM AND THE PROUD BOYS 26 


\section{INTRODUCTION}

During his presidential term, Donald Trump showed more sympathy for far right and extremist groups than any US president in recent memory. Prior to his term, white supremacists, white nationalists, and other far-right extremist groups operated mainly on the political margins and could expect condemnation from most mainstream politicians. However, Trump's rhetoric has lent legitimacy to their agendas. His administration also pressured law enforcement agencies to downplay the threat posed by these extremist groups. Thus, it created a permissive atmosphere for such groups to operate in (Matanock \& Staniland, 2020), and extremists have been increasingly emboldened (Crowell \& O’Regan, 2019).

On January 6, 2021, a ragtag band of Trump's extremist supporters shocked the world when they stormed the US Capitol Building, leaving a trail of destruction and violence in their wake. When all was said and done, five people, including a police officer, were dead. Though the invaders were made up of a bizarre patchwork of far-right groups, conspiracy theorists, and lone wolves, a significant proportion of those pictured at the scene affiliated themselves with the Proud Boys. In recent months the group has become synonymous with violent opposition to the Black Lives Matter and Antifa movements (Greig, 2021). It raises the question: who are the Proud Boys?

The Proud Boys are a far-right, anti-immigrant, all-male group who have been known to use violence against left-wing opponents (Greig, 2021). The group describes themselves as "Western chauvinists," by which they mean "men who refuse to a pologise for creating the modern world" (McBain, 2020). According to Kutner, the Proud Boys are the new face of far-right extremism, one that recruits through shared precarity and male grievances (Kutner, 2020). Meanwhile, others define it as a neo-fascist and white supremacist organization that promotes and engages in political violence in a number of countries, including the US, Canada (MacFarquhar et.al., 2020), Australia (Culkin, 2017), several European countries, and even Israel (Israel Faxx, 2020). Vitolo-Haddad (2019) is right to define the Proud Boys as "a multinational fraternal organization" that uses an aesthetic of libertarianism to advance a fascist politic.

\section{9}

The Proud Boys is a strange amalgamation of a men's rights organization, a fight club, and what some may see as a hate group - one that loves Trump and hates Muslims, Jews, and trans people but permits non-white membership. 


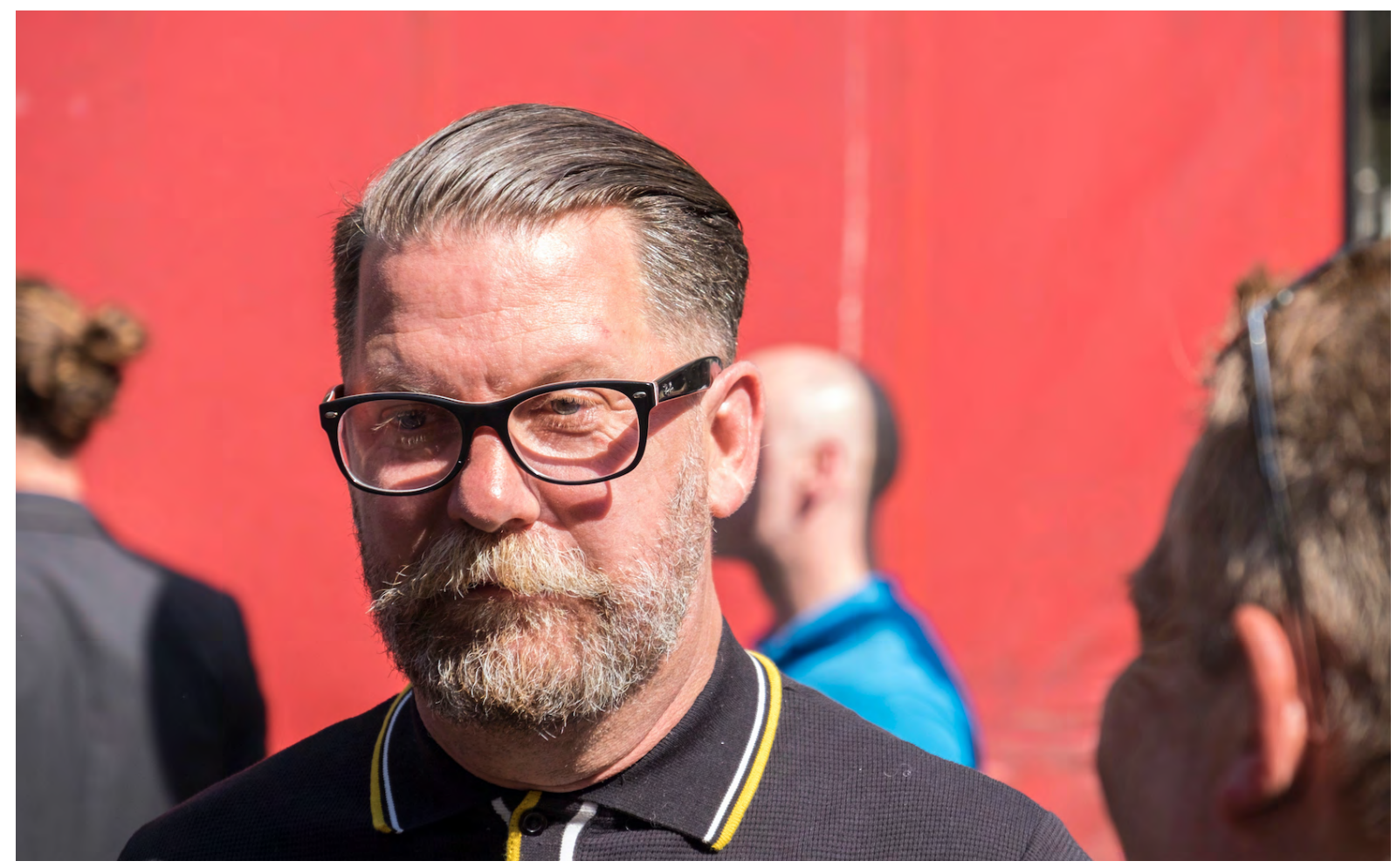

Gavin Mclnnes

The Proud Boys was founded by noted racist, anti-Semite, and Islamophobe Gavin McInnes, Vice Media's co-founder and former commentator, a "provocateur" who has described himself as "an old punk from Canada." McInnes turned to the political right in 2008 and introduced the Proud Boys to the larger public (Mclnnes, 2016) on September 15, 2016. According to Coaston (2018), the group is a strange amalgamation of a men's rights organization, a fight club, and what some may see as a hate group - one that loves Trump and hates Muslims, Jews, and trans people but permits non-white membership. The group took its name from the song "Proud of Your Boy" from the Disney musical Aladdin.

While the Anti-Defamation League (ADL) describes the group as "misogynistic, Islamophobic, transphobic and anti-immigration" (McBain, 2020), the Southern Poverty Law Centre (SPLC) designated the Proud Boys as hate group who "regularly spout white nationalist memes and maintain affiliations with known extremists (Mom Demand Action, 2020). "What really defines the Proud Boys is their activity on the ground, so their proclivity to violence and their consistent presence as a counter-movement to left-wing protests," said Jacob Davey, a senior researcher focusing on the far-right. Joseph Lowndes, a political science professor, described them as an "authoritarian group focused on the glorification of male violence," more an "overblown street gang" than a well-organised militia (McBain, 2020).

The Proud Boys have appeared alongside other hate groups at extremist gatherings like the "Unite the Right" rally in Charlottesville, Virginia, where they made national headlines in August 2017. The rally was advertised as a protest about the removal of confederate statues (Stolberg \& Rosenthal, 
2017). Later, it was proven to be a pretext for a violent show of force (Sankin \& Pham, 2017). After one woman was killed and 19 others were seriously injured in a vehicular attack, McInnes "disavowed" Proud Boys who attended (Barnes, 2017).

The next year, in 2018, the group was temporarily classified as an extremist organization by the FBI (Kutner, 2020) after the group was involved in a violent clash with anarchists on the streets of Manhattan, following an event in which McInnes portrayed Otoya Yamaguchi, a young far-right extremist who assassinated the leader of the Japanese Socialist Party (Coaston, 2018). Because of this clash, Mclnnes stepped down from his role as the Proud Boys' leader, stating he would no longer be involved with the group in any capacity (Wilson, 2018). In a video, McInnes said, "I am officially disassociating myself from the Proud Boys. In all capacities, forever, I quit." He added, "I'm told by my legal team and law enforcement that this gesture could help alleviate their sentencing," referring to the Proud Boys who were facing legal problems (Coaston, 2018). Since early 2019, Enrique Tarrio, an Afro-Cuban American who briefly ran for Congress, has been the chairman of the Proud Boys (Sidner, 2020).

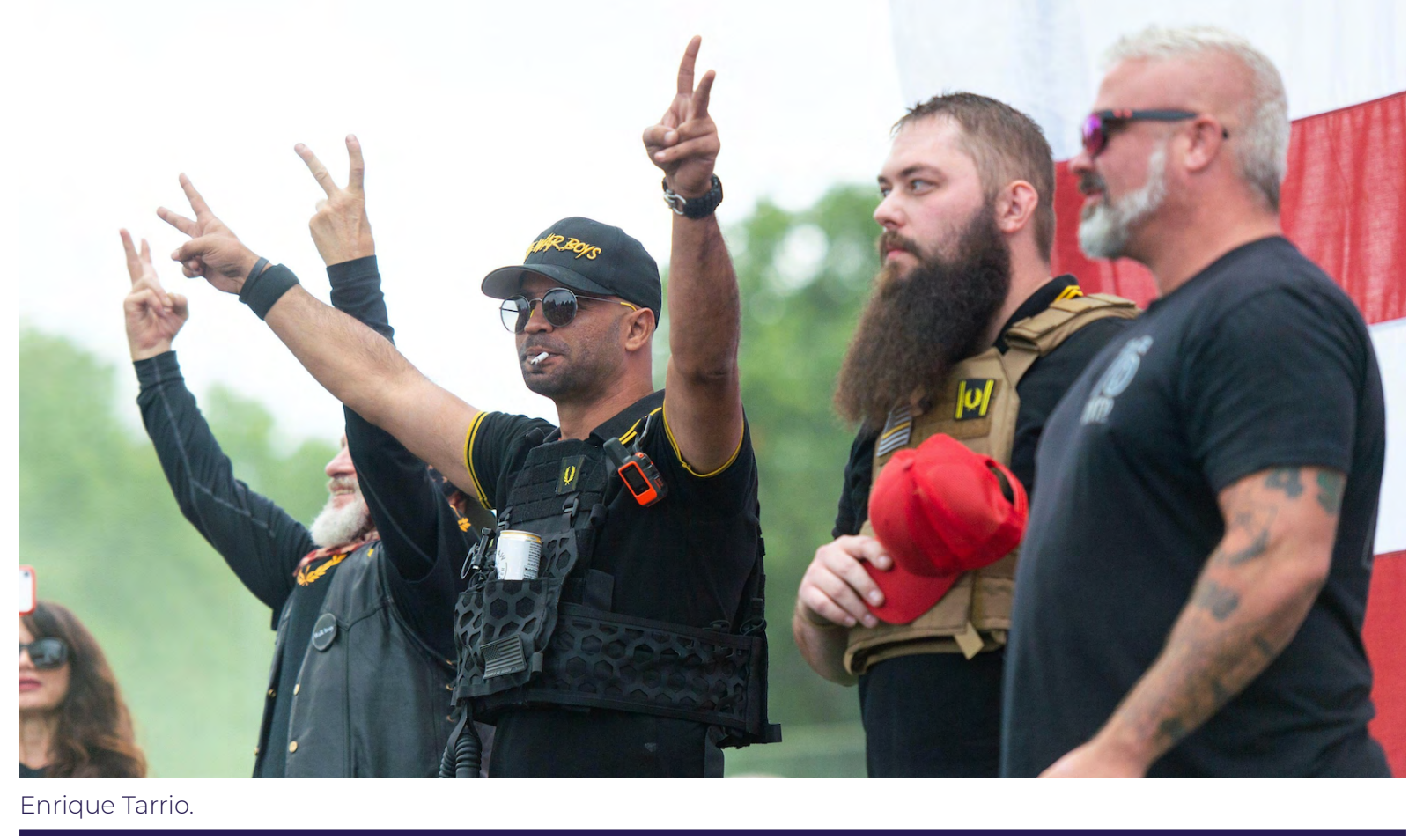

According to the group, there are four levels of Proud Boy membership. The first is to declare yourself to be a Proud Boy. "This means you make your Western chauvinism public and you don't care who knows it" through declaring that "I am a western chauvinist, and I refuse to apologize for creating the modern world" (SPLC, 2021). The second level is the swearing-off of masturbation known online as "nofap" or \#NoWanks combined with a "cereal beat-in" - if you want into the group, you have to get beaten up while suc- 
cessfully reciting the names of five breakfast cereals, because "defending the West against the people who want to shut it down is like remembering cereals as you're being bombarded with ten fists." The third level is to get a specific Proud Boys tattoo. But it's the fourth and newest level that gets the most attention: get into a physical altercation for the "cause." "You get beat up, kick the crap out of an Antifa," McInnes explained in 2017 (Coaston, 2018). Tarrio got involved with the Proud Boys after volunteering at an event for the far-right commentator Milo Yiannopoulos in 2017 and became a fourth-degree Proud Boy after punching a member of Antifa in the face in June 2018 (Coaston, 2018). 


\section{Cultural Hijacking: Repurposing Uhuru}

The Proud Boys' loose organisational structure makes it hard to estimate its overall size; most experts suggest there are several thousand members, spread across the US and a handful of international chapters (McBain, 2020). Though the total number of Proud Boys members is unknown, reports estimate membership between several hundred up to 6,000 (Greenspan, 2020). For instance, the website Rewire estimates there are roughly 6,000 members (SPLC, 2021). The leader of the group estimated that the numbers are closer to 8,000 , but this number is likely inflated (Kutner, 2020).

Some members of the group are high-profile. The political operative and Trump adviser, Roger Stone - whose 40-month prison sentence for lying to Congress, witness tampering, and obstruction of justice was commuted by the president - was videoed taking the Proud Boys oath. During his trial Stone testified that some Proud Boys had helped him run his social media accounts. Jason Kessler, one of the organisers of the rally in Charlottesville, was a Proud Boy. The founder of the English Defence League, Tommy Robinson, also has links to the group (McBain, 2020).

Members are known for a provocative practice called cultural hijacking, in which the symbols and language of civil rights leaders are repurposed to advance farright narratives. The intent is not to appropriate civil rights symbolism, but to weaken the communicative power of groups from which the symbols originated. After hijacking these terms, they ascribe new labels to the groups they have hijacked them from. Civil rights activists become social justice warriors, snowflakes, or the intolerant left. Of the culturally hijacked terms, the most commonly used is Uhuru - Swahili for African solidarity. Proud Boys have repurposed Uhuru as a rallying cry, in a manner similar to the military use of Oohrah used in the US Navy (Kutner, 2020).

The Proud Boys have emerged by reject- ing mainstream conservatism, which they often view as a failure (DeCook, 2018).The group is distinct from other neo-conservative movements because of their heavy and strategic use of social media, and although other factions of the alt-right are known for their digital media savvy, the Proud Boys have specifically harnessed the power of digital technologies and have used Instagram, Facebook, and other platforms for recruitment, identity reinforcement, and to highlight the visibility of members in the world (DeCook, 2018). Social media serves a function of not only organizing and recruitment, but also serves as an educational and socialization space (Jacoby \& Ochs, 1995). The group uses memes specifically as a means of spreading propaganda. These memes are bite sized nuggets of political ideology and culture that are easily digestible and spread by netizens (DeCook, 2018). Thus, memes themselves are a form of political participation within larger social movements and are an important facet of identity and community building (Mina, 2018; Nagle, 2017; Shifman, 2014) and as a vehicle to express either an individual or a collective voice (Freund, 2013; Nagle, 2017; Paddock, 2015).Memes are an extension of spoken utterances through visual and digital means (DeCook, 2018).

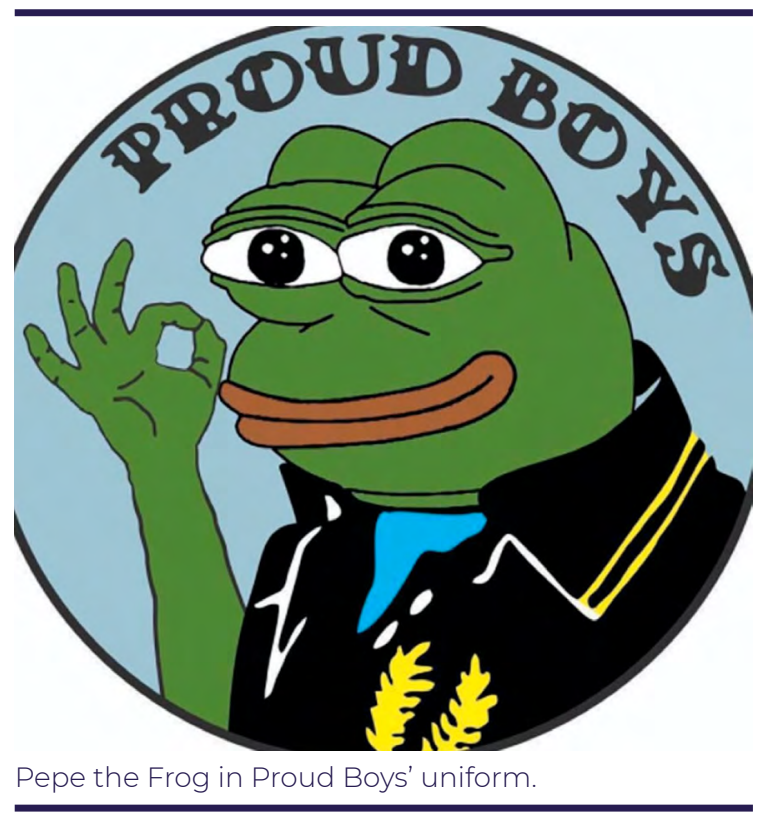

Further, the use of the cartoon character Pepe (the frog) - which was co-opted by the larger alt-right as a symbol - has been used to build group identity as well (ADL, 2016). The Proud Boys depict Pepe wearing the Proud Boys' uniform and 
flashing the "OK" hand symbol used by white supremacists. As with other fascist aesthetics, the Proud Boys use clothing and branding in order to cement their group membership and to make their political and ideological affiliation visible. Their group mantra of 'West is the Best' is often used in their memes, their posts, and symbols of American masculinity are used in recruitment memes. The aestheticization of their political ideology goes a step further through the usage of tattoos. These tattoos symbolize not only a progression in rank into the organization and the members' allegiance to the Proud Boys, but also function as an aesthetic quality along with the uniforms, the hashtags used to gain visibility online, and other symbols (DeCook, 2018).

However, the Proud Boys have seen their digital reach limited; the group has been banned by social media platforms Facebook, Instagram, Twitter, and YouTube (Wendling, 2020; Murphy, 2020). In August 2018, Twitter terminated the official account for the group, along with McInnes' account, under its policy prohibiting violent extremist groups (Roettgers, 2018). Facebook and Instagram also banned the group and Mclnnes in October 2018 (CBC, 2018). That same year, in December, YouTube banned the Proud Boys founder for copyright violation (Solsman, 2018). In February 2019, Slate magazine reported that Square, Chase Paymentech, and PayPal had pulled their payment processing services from 1776.shop, an online far-right merchandise site associated with the Proud Boys (Glaser, 2019).

In light of mass deplatforming, as well as the right-wing social network Parler going dark, everyone from casual Trump supporters to far-right militants have been flocking to alternative social networks such as the encrypted messaging apps Telegram and Signal. In particular, the Proud Boys is making a substantive play at organizing on Telegram. Two major Proud Boys channels on Telegram have exploded in use by at least 69 percent and 83 percent since January 5, 2021(Dickson, 2021).

\section{A Supremacist} Alt-Right Organisation Pretending to be Alt-Lite

The Proud Boys emerged as part of the alt-right. However, its founder Mclnnes distanced himself from this movement in early 2017, saying the Proud Boys was "alt-light" (Marantz, 2017) despite his and the group's overt xenophobia and racism. Mclnnes told the New York Times in 2003 that "I love being white and I think it's something to be very proud of. I don't want our culture diluted. We need to close the borders now and let everyone assimilate to a Western, white, English-speaking way of life" (Widdicombe, 2013; Grigoriadis, 2003). Nevertheless, Mclnnes alleged that "they (alt-right) care about the white race. We care about Western values." This is a view that has come to be known as "civic nationalism," as opposed to white nationalism - or "alt-light," as opposed to altright (Marantz, 2017). The ADL also defines the group as part of the alt-lite (ADL, 2021), although they are routinely associated with the "alt-right."

Mclnnes's insistence that the Proud Boys have nothing to do with the "altright" grew even more adamant after the violence during the Unite the Right rally in Charlottesville. In a blog post titled "We are not alt-right" in August 2017, he alerted his group that "alt-right" members planned to "infiltrate" Proud Boys meetings and "sabotage" them (Woodhouse, 2017). The article stated that the Proud Boys did not concur with the alt-right regarding the Jewish Question and racial identity politics (Kutner, 2020). The violence in Charlottesville sharpened the divide between the "alt-right" and the "altlight," but it may be a distinction without a difference (Woodhouse, 2017).

Despite also denying the group's racism, Mclnnes himself has ties to the racist right. He has contributed to hate sites like VDare.com and American Renaissance, 
both of which publish the work of white supremacists and so-called "race realists." He even used Taki's Magazine - a far-right publication whose contributors include Richard Spencer and Jared Taylor - to announce the founding of the Proud Boys (SPLC, 2021). The ADL says McInnes has previously posted videos of himself giving the Nazi salute, saying, "Heil Hitler," defending Holocaust deniers, and repeatedly using racial and antisemitic slurs (Murphy, 2020).

Obviously, Mclnnes plays a duplicitous rhetorical game: rejecting white nationalism and the term "alt-right" while espousing some of its central tenets. In the spring of 2015, he formed a partnership with the Canadian far-right Rebel Media and launched "The Gavin Mclnnes Show" with Compound Media. On both platforms, he regularly chatted with rightwing guests and carved out an ideological space for frustrated young men to rally around: western culture is superior to all others, racism is a myth created by guilty white liberals, Islam is a culture of violence, and feminism "is about de-masculinizing men," he told his audience (SPLC, 2021).

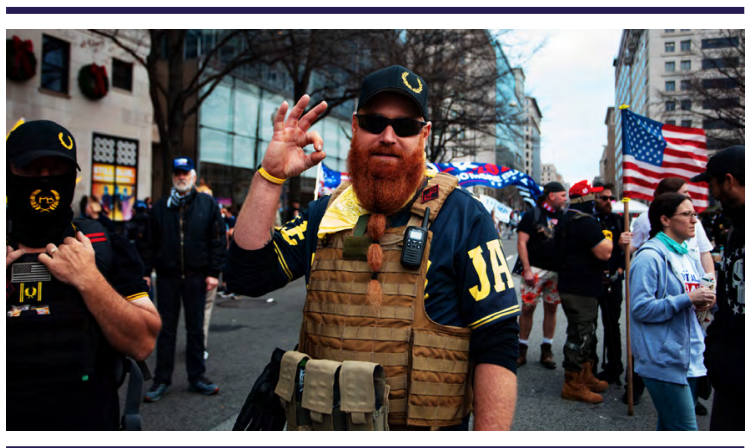

Despite leaders claiming they disavow racism, the Proud Boys have ties to white supremacists and sometimes use nationalist rhetoric common among hate groups (Hawkins, 2021). The attempt to distance their organization from the altright may be an intentional, image-saving move in order to remain appealing to the larger public and to attract more members. These strategies are a way for the Proud Boys to adapt to their wider audience's views of the organization (Bourdieu 1991). Pragmatically sidestepping the question of race, the Proud Boys make their protofascist appeal in the language of patriotic individualism: pro-America, pro-capitalism, and pro-Trump. This strategy has allowed them to gain entry into the Republican mainstream. They're also shifting from ethnically defined nationalism to a version that purports to target outsiders based on their legal status, not the colour of their skin. O'Connor hints (2021) that the Proud Boys is dangerous because it functions as a "pipeline" to even more violent ideologies. In a 2018 survey conducted by the SPLC of users on the Right Stuff forums, 15 percent of respondents mentioned Mclnnes as either an important influence on their political development or as useful in converting others (Miller, 2018).

Functioning similarly to a religious group, Mclnnes acted as the leader of the movement and a prophet of sorts for years. The members operate the organization under the belief that "The West is the Best," but welcome non-white members as long as these members acknowledge that Western civilization is superior to all others (Sommer, 2017). Furthermore, their views have elements of the white genocide conspiracy theory (Walters, 2017), and some members espouse white supremacist and antisemitic ideologies and/or engage with white supremacist groups (ADL, 2021). What the Proud Boys promise is a space for "pro-Western Chauvin[ist]" men to have their views and beliefs supported, to mingle with like-minded others, and to hopefully shift the world back towards their favoured ideology (DeCook, 2018).

\section{A Libertarian-Fascist Movement That Venerates Housewives}

The Proud Boys lists among its central tenets a belief in "closed borders" and the aim of "reinstating a spirit of Western chauvinism" (Murphy, 2020). An introductory article in Proud Boy Magazine professes thirteen core tenets, which combine patriarchal and patriotic ideals with libertarian, anti-government rhetoric: 
minimal government, maximum freedom, anti-political correctness, anti-drug war, anti-masturbation, closed borders, anti-racial guilt, anti-racism, pro-free speech, pro-gun rights, glorifying the entrepreneur, venerating the housewife, and reinstating a spirit of Western chauvinism (Elders, 2018).

The combination of militaristic rhetoric, violence on behalf of sovereign authority, radically traditional gender roles, glorification of entrepreneurship, and closed-border policies situate the group within a growing libertarian-fascist movement. Despite purporting to oppose government tyranny, the Proud Boys' values exemplify the slippage between right-libertarianism and fascism (Vitolo-Haddad, 2019), working toward what Michael Orth (1990) described as a "libertarian Utopia which combines violence, repression of women, and a dictatorial state into an all-American Utopia which emits strong fascist resonances." Similarly, political scientist Adolph Reed, Jr. (2013) argues that this contradiction is inevitable in right-wing libertarianism, and the Proud Boys adopt a libertarian "aesthetic" of freedom to promote a politics that is often authoritarian.

Moreover, negative precarity and the need to fight to prevent the perceived extinction of western culture has been a central factor in the Proud Boys' recruitment (Kutner, 2020). Paul Elliott Johnson (2017) states that allusions to the concept of negative precarity are found in repeated images Proud Boys disseminate in their groups. "These images construct a new perception of reality based on precarity as a white, working-class American male at risk of losing his place in society amidst changing demographics and issues surrounding immigration," according to Johnson. Members are motivated by attempts "to establish political, social, or cultural superiority as a springboard for action on behalf of social change" (Goldzwig, 1989: 208). The belief that Western culture is superior begets a belief that members of other cultures should have less freedom, power, and opportunity, which is seen simply as the natural outcome of not being part of the Western ingroup. Proud Boys believe that they have entered a "soft civil war" with battle lines drawn not by ideology, but by association and identity (Vitolo-Haddad, 2019).

The Proud Boys' beliefs vary from the call to "give everyone a gun" and "end welfare" to a return to traditional gender roles (Greig, 2021). They represent an unconventional strain of American rightwing extremism (ADL, 2021). Therefore,repeated warnings about the Proud Boys as a dangerous white supremacist group were issued by counterterrorist centres. In a 22-page, 2019 document published by the Colorado Information Analysis Center $(C \mid A C)$, various incidents of violence involving the Proud Boys are discussed under the heading of "White Supremacist Extremism." CIAC described how "the Proud Boys has been active in spreading conspiracy theories regarding Covid-19 on Twitter, Facebook, and Telegram," suggesting that "a faction of elites are weaponizing the virus, and a vaccine would likely be a tool for population control and mind control" (Wilson, 2020). The FBI also lists the Proud Boys as an extremist group while Southern Poverty Law Center has labelled them a hate group (Greig, 2021).

Like other white supremacist networks, the Proud Boys believes that whites have their own culture that is superior to other cultures, are genetically superior to other peoples, and should exert dominance over others. They also adhere to the "Great Replacement" conspiracy. This conspiracy claims that whites are being eradicated by ethnic and racial minorities, including Jews and immigrants (McAleenan, 2019). Brenton Tarrant, the Christchurch shooter in New Zealand, and Patrick Crusius, the El Paso Walmart shooter, espoused the most radical view of the Great Replacement conspiracy, known as Accelerationism (Jones et al, 2020).

Although not outwardly a religious organization, one of the key factors of the Proud Boys' ideology is embracing Christianity because of its association with Western civilization. The Proud Boys magazine had an article denouncing atheists, stating that "Christianity is the Western Religion." The ideology and the use of phrases like "Deus Vult" point to the group's religious element, as well as the fraternity-esque concepts of brotherhood. The Proud Boys is not necessarily a religious movement that is acting as a 
social movement, but rather one that is harnessing religion to invoke nostalgia for the past and as an element of their larger desire to impose a specific moral order (DeCook, 2018). Postings on GiveSendGo, a niche Christian fundraising website, show that at least $\$ 247,000$ has been raised for at least eight members of the Proud Boys (Brittain \& David, 2021).

Meanwhile, calls to "murder Antifa" and memes jokingly posting "Antifa hunting permits," are further examples of the call for violent acts to eradicate what the group views as their political opponents. For Proud Boys and other organizations in the alt-right sphere, Antifa is the true enemy of the Christian, white ethnonationalist west because of their embrace of socialism and multiculturalism (DeCook, 2018). By positioning Antifa as the enemy, the solidification of an "out-group" strengthens the "in-group" identity (Tajfel 1978). But members' skill at wielding irreverence, mocking political correctness, and hewing close to views espoused by mainstream conservatives has allowed the Proud Boys to camouflage their most dangerous ideologies and flourish where other groups have withered (Hawkins, 2021). The group has historically attempted to market itself towards the Republican mainstream on platforms such as Facebook by deliberately avoiding the use of overtly racist symbols (Crawford, 2020). 


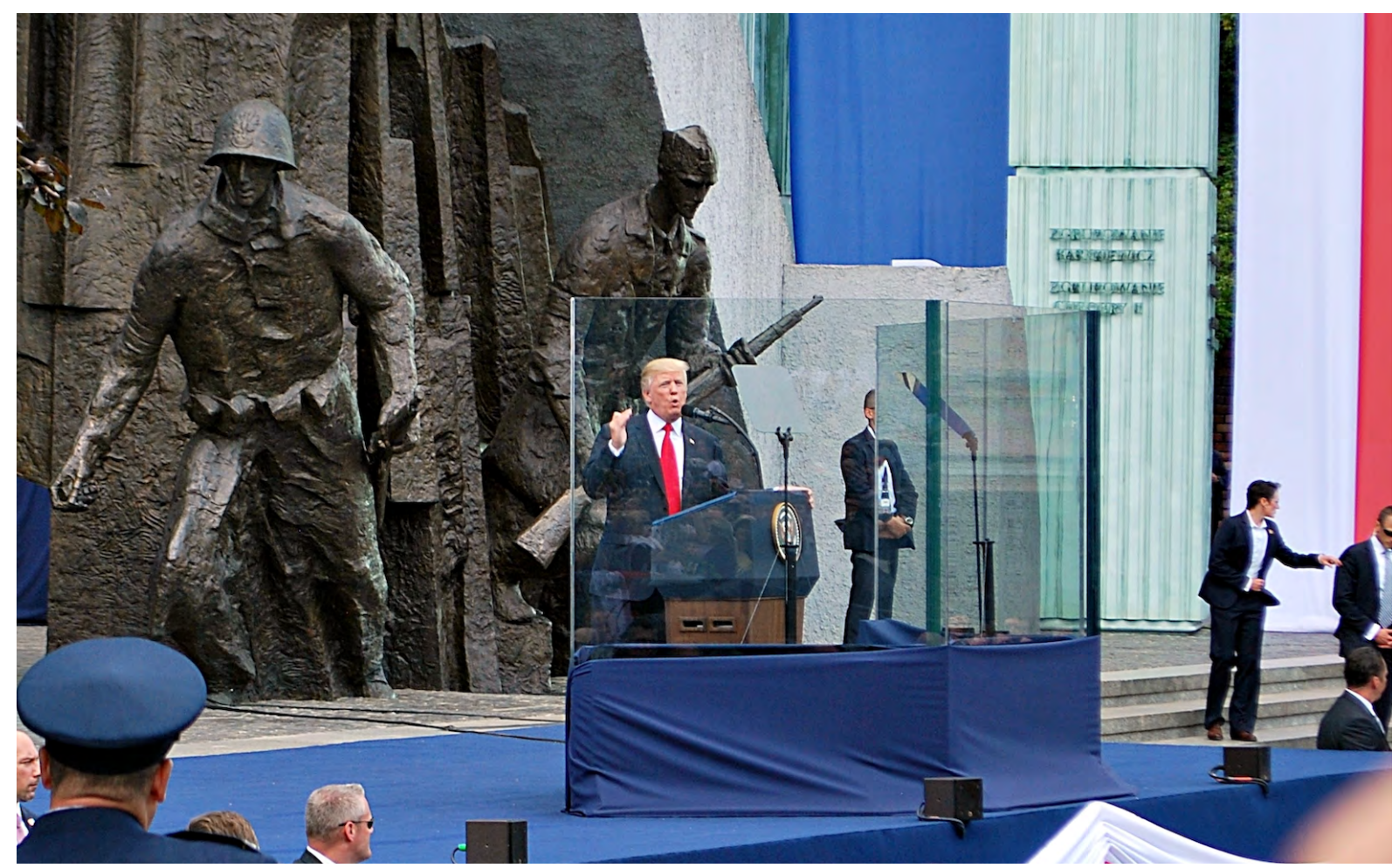

US President Donald Trump gave a speech to the People of Poland at Krasinski Square in Warsaw on July 6, 2017.

\section{The Proud Boys}

\section{Found A Soulmate In Donald Trump}

On the night of the US presidential election on November 3, 2016, the Proud Boys gathered to await the possibility of "a cultural change" in the country. Proud Boys' founder Mclnnes announced, "Tonight, we either take the country or we lose the country to the establishment" (Bazile, 2017). Attendees of the Proud Boys' election night party repeated their mantra: "I am a Western chauvinist who refuses to apologize for creating the modern world" (Vitolo-Haddad, 2019).

Two months later, in his inaugural speech, President Donald Trump contrasted the "forgotten people" with a corrupt elite. Trump's "American people," like the Proud Boys, were the people who "do not believe the corrupt fake news anymore." As used by Trump, "the people" is both a rhetorical construction and an embodied metaphor found in phrasing like "the incredible patriots here today" and "the magnitude of the crowd" stretching "all the way to the monument in Washington." For the president, size is a sign of moral virtue: "As this enormous crowd shows," he said, "we have truth and justice on our side" (Viala-Gaudefroy, 2021).

The demagogue atop the Proud Boys' political reality, their "God Emperor," Trump utilizes a rhetoric of victimization to call on the impatient masses to reclaim their power and agency. Johnson (2017: 230) describes Trump's demagoguery as "a toxic, paradoxically abject masculine style whose incoherence is opaque to his critics but meaningful to his adherents, for it helps them imagine themselves as victims of a political tragedy centred around the displacement of 'real America' from the political centre by a feminized political establishment." Fortunately, for the "real Americans" in this political tragedy, Trump provides a solution: fight for the West (Vitolo-Haddad, 2019). In his remarks in Poland, in 2017, Trump reminded the patriots "that every foot of ground, and every last inch of civilization, is worth defending with your life"(YouTube, 2017).

The Proud Boys find symbolic identification with the West as articulated by President Trump, figured as the leader of 
a fight that is inevitably victorious because of the inherent superiority of the Western warrior caste. So long as patriots continue in the ritualistic sacrifice of themselves, history is converted into a promise: "The West will never, ever be broken. Our values will prevail. Our people will thrive. And our civilization will triumph." America must be made great again, and again, and again, so "that each generation must rise up and play their part in its defence." Trump's promise was predictably appealing to rural voters, but that the Proud Boys were catalysed by his victory to operate in the mainly metropolitan areas where they live, reflecting how truly mainstream the Proud Boys' beliefs are. In other words, Trump did not enchant new believers in an ideology that they had never heard, but rather coherently pieced back together an identity that reproduces itself through masculine violence (Vitolo-Haddad, 2019).

As political parties have been overtaken by political tribes (Fukuyama, 2021), the Proud Boys viewed Trump's election as a reclamation of their sovereign authority to govern by force, particularly in defence of "the West" - that spatial organization of whiteness described by Trump in Poland as "worth defending with your life" (Trump, 2017). Spellbound by demagogic rhetoric and the mythos of "the West," the Proud Boys interpreted Trump's election as tacit authorization to follow a pathway to self-empowerment achieved through violence (Vitolo-Haddad, 2019). As Perry stated, the seeds sowed by Trumpism have begun to bear fruit and the harvest is rather rotten. Trump openly pandered to white racial resentment in the 2016 election and was awarded the most important job in the world (Perry, 2018).

A study by Leonardo Bursztyn of the University of Chicago found that Trumpism hasn't bred more racists in the US - but it has emboldened people with xenophobic views to feel more comfortable expressing them in public. It's impossible to separate the growing visibility of white supremacists under the guise of the alt-right without associating it with Trumpism. Now, more candidates with white supremacist ties are emerging from the shadows to run for public office. Spencer Sunshine, who follows white nationalist movements, explained that the "ideas of the alt-right are now part of the GOP" (Strickland, 2018). In Trump, they have found empowerment, a call to mass, warlike action aimed at reinforcing a universalized white, male, heterosexual, and entrepreneurial political subject. While right-wing, "patriot" militias are not new in the US, they have primarily mobilized in rural areas and have often fixated on liberatory militancy (Durham, 1996).

America's white supremacists, who were explicit in saying they felt emboldened by President Trump, have held rallies across the country. The Proud Boys have been filmed marching through the streets, chanting, "Pinochet did nothing wrong!" (The phrase is a reference to former Chilean dictator Augusto Pinochet's penchant for murdering leftists by throwing them out of helicopters into the ocean (Mathias, 2020)). Early in Trump's presidency, emboldened neo-Nazi and fascist groups came out into the open but were met with widespread revulsion. Thus, the tactics of the far-right changed, becoming more insidious - and much more successful (O'Connor, 2021).

John Cohen, a former counterterrorism coordinator at the Department of Homeland Security and now an adjunct professor at Georgetown University's Center for Security Studies, said white supremacists have become more sophisticated in their communication. "In the past they were viewed as racist individuals who were on the fringe or outside of mainstream society. Now their thoughts and ideas and messaging have been incorporated into the mainstream political discourse by a growing number of elected officials," said Cohen (Ortiz, 2020). Media Matters, a not-for-profit progressive research centre which monitors misinformation, has counted 97 right-wing congressional candidates who have embraced QAnon, a conspiracy theory based in antisemitic tropes which has incited supporters to violence and is popular among Trump supporters (Kaplan, 2020).

In October 2019, Donald Trump, Jr. posed for a photo with Proud Boy member Luke Rohlfing. The photo is part of the Proud Boys' strategy: posing alongside high-level Republicans to gain legitimacy. 
Both US Sen. Ted Cruz and then-Florida Gov. Rick Scott have been photographed alongside Proud Boys, as have US Reps Mario Diaz-Balart and Devin Nunes. Cruz took his support a step farther, backing a non-binding resolution that would have defined anti-fascist activists as domestic terrorists after Enrique Tarrio launched a petition in favour of the bill (ADL, 2021). Tarrio would later be named Florida state director of Latinos for Trump. As one Republican operative later said, "The Trump campaign is well aware of the organised participation of Proud Boys rallies merging into Trump events. They don't care," (O'Connor, 2021).

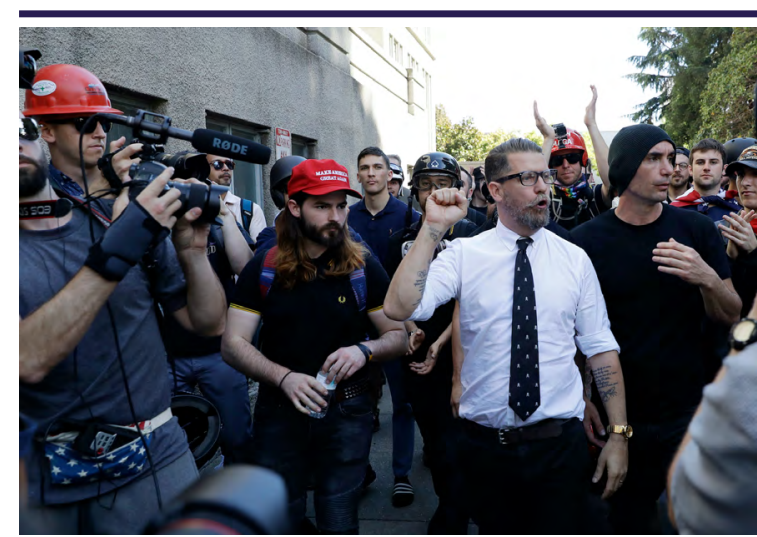

Gavin Mclnnes march together with his Proud Boys in Washington DC on December 13, 2020.

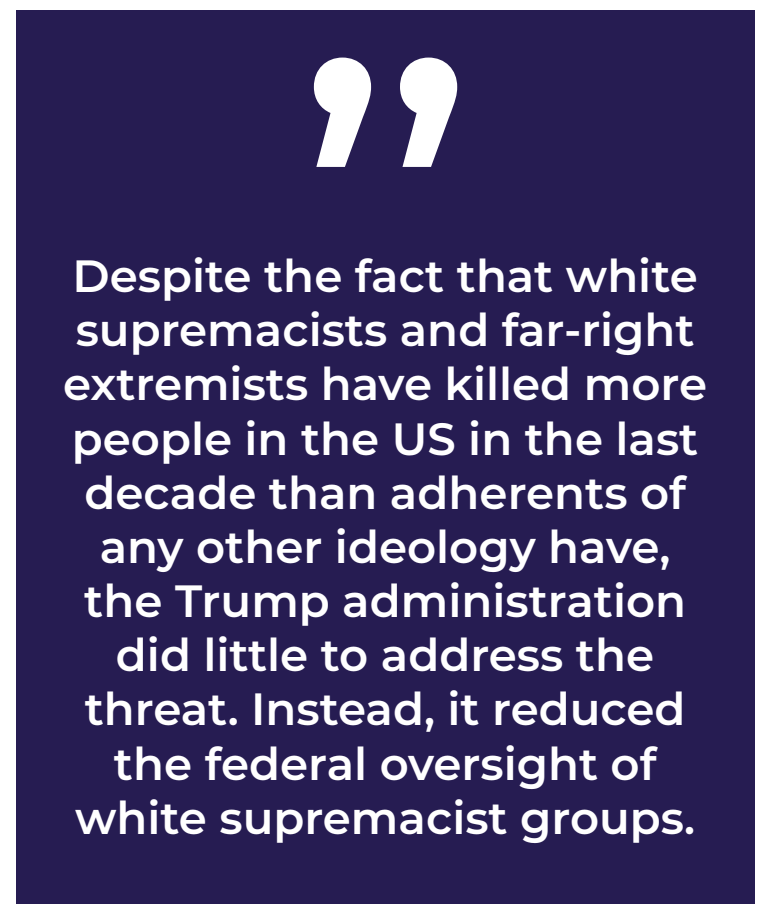

The Proud Boys began to grow into something very few had expected: a hegemonic force on the far-right able to appeal to mainstream conservatives, carv- ing out a space for white nationalists and fascists. They observed Richard Spencer and Traditionalist Worker Party (TWP) chair Matthew Heimbach's mistakes. Their more moderate strategies have won them greater appeal by foregrounding ultranationalism and a vicious opposition to left-wing politics. Getting closer to the mainstream of American conservatism has made the Proud Boys even more dangerous. They have received sympathetic media coverage from Fox News, while actively recruiting new members not only from the far right but from racist skinhead groups across the country. It's no accident that the Proud Boys chosen uniform features black and yellow shirts by Fred Perry - a favoured skinhead brand (O'Connor, 2021).

The Proud Boys and the far-right - once fringe white nationalist groups - have increasingly infiltrated the mainstream of American political and cultural discussion, with poisonous results. One must look no further than President Trump's senior adviser for policy and chief speechwriter, Stephen Miller, to see this deleterious effect. In December 2019, the SPLC's Hatewatch published a cache of more than 900 e-mails Miller wrote to his contacts at Breitbart News before the 2016 presidential election. In the emails, Miller, an adviser to the Trump campaign at the time, advocated many of the most extreme white supremacist concepts. These included the "great replacement" theory, fears of "white genocide" through immigration, race science, and eugenics; he also linked immigrants with crime, glorified the Confederacy, and promoted the genocidal book, The Camp of the Saints, as a roadmap for US policy (Clark, 2020).

Yet thankfully, public attitudes have generally changed for the better. A public survey shows American attitudes toward racial integration and immigration have become more open among liberals and conservatives alike, with two-thirds of Americans in a recent Pew Research Center survey saying that "openness to people from all over the world is essential to who America is as a nation" (Pew, 2019). In such a changing landscape, old-fashioned racist and xenophobic appeals are unlikely to be politically successful beyond a small fringe, so the propagandists of racism 
have had to develop subtler approaches to stoking fear and hatred for political ends (Clark, 2020).

Trump opened his 2016 presidential campaign by claiming Mexico was sending drug dealers and rapists to the US. Once in office, he followed those proclamations by implementing a travel ban on majority Muslim countries and later refused to condemn white supremacists (Gabbatt, 2020). His rhetoric surrounding immigration is where he appears to most closely align with white supremacist concepts. Stopping immigration is the central aim of white nationalism, as white nationalists see this as the only way of stopping immigrants from taking power away from a white majority. To achieve their goal, white nationalists have typically tied the diversification of America to a Jewish plot (Clark, 2020).

Equating immigration with an "invasion" was a common tactic of Trump's campaign. According to research by Media Matters, in January and February 2019 alone, Trump's Facebook page ran more than 2,000 ads using that term. The former president is far from the only elected leader to make that analogy, but his voice carries the farthest. "When you have the person with the biggest bullhorn not only in the country but in the world using this language, doesn't that give cover to other people to use it?" said Colin P. Clarke, who is a senior research fellow at The Soufan Center (Ortiz, 2020).

Proud Boy Derek Wray identified the radical traditionalism within the proTrump movement and "a new wave of nationalist populism" that "swept America ... under the premise of putting America First" (Wray, 2017). These views are what undergirded the chant, "You will not replace us. Jews will not replace us," (Gabbatt, 2017) at the 2017 rally in Charlottesville, Virginia, where a white nationalist murdered a woman and injured 35 others. President Trump's response to the riot saying that there were "very fine people, on both sides" (Holan, 2019) - provided implicit support for these positions. Notably, the former president did not oppose all immigration; for example, he has said that immigrants from Norway would be welcome in the US (Kirby, 2018).
According to the Anti-Defamation League, the deadly "Unite the Right" rally in 2017, in which 600 far-right supporters clashed with anti-racist protesters in Charlottesville, was a "wake-up call" that white supremacist groups were resurgent. But despite the fact that white supremacists and far-right extremists have killed more people in the US in the last decade than adherents of any other ideology have, the Trump administration did little to address the threat. Instead, it reduced the federal oversight of white supremacist groups. Soon after taking office, Trump cut the Department of Homeland Security's budget for terrorism prevention (Crowell \& O'Regan, 2019).

In 2018, then-attorney general Jeff Sessions, who once joked that he thought KKK members "were OK until I learned they smoked pot," signed a memorandum that restricted the Justice Department's ability to oversee troubled police departments, including the 14 that had agreed to be monitored under the Obama administration because of their records of racial discrimination and police abuse. In early 2019, the FBI revealed that it had changed its classification system for terrorism cases. While there were once 11 categories, including a specific one for white supremacy, the new list featured just four, including the catch-all "racially motivated violent extremism." This change means it's now harder to narrow down exactly what resources the $\mathrm{FBI}$ is putting toward the specific threat of white supremacy (Crowell \& O’Regan, 2019).

Elizabeth Neumann, former assistant secretary of counterterrorism at the Department of Homeland Security, had a front-row view of the surge of right-wing extremist activity in the Trump era. She said that in her position, she tried to get Trump to take this sort of right-wing extremism far more seriously yet was unable to do so. "He was given the opportunity to condemn White Supremacy," Neumann said, "He refused." When Trump declines to offer unequivocal condemnation of them, they understand this as tacit support (Sargent, 2020).

Trump also refused to condemn white supremacists during a bellicose first presidential debate in 2020 , during which rac- 


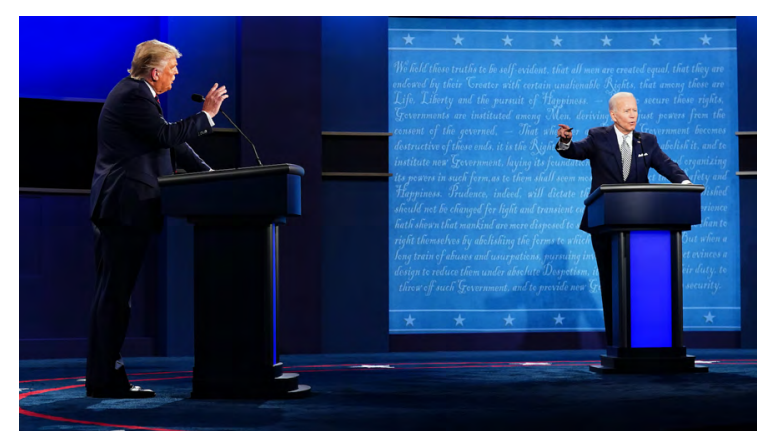

US President Donald J. Trump and Democratic presidential candidate Joe Biden participate in the first presidential election debate at Samson Pavilion in Cleveland, Ohio, US, 29 September 2020.

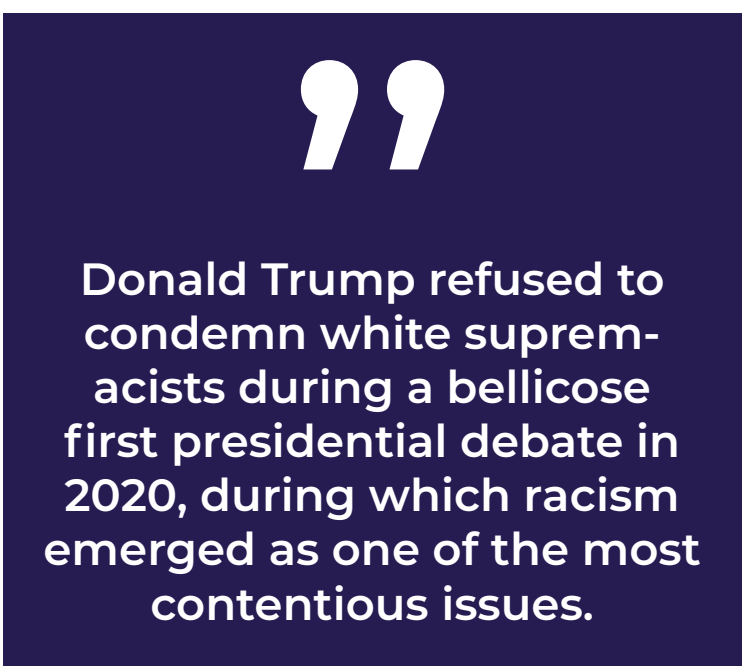

ism emerged as one of the most contentious issues. The exchange came almost an hour into the debate, with moderator Chris Wallace asking Trump to directly address his supporters and urge calm. "Are you willing to condemn white supremacists, and militia groups and to say that they need to stand down and not add to the violence in a number of these cities?" Wallace said. After initially saying "sure," Trump said, "I'm prepared to do that, but I would say almost everything I see is from the left wing, not from the right wing" (Olorunnipa \& Wootson, 2020).

Pressed by Biden to directly rein in his supporters, Trump said, "What do you want to call them? Give me a name... who would you like me to condemn?" When Biden said, "Proud Boys," Trump responded by telling the group to "stand back and stand by," terminology that was seized by both Trump's detractors and members of the group. "This is not a right-wing problem; this is a left-wing problem," Trump said (Olorunnipa \& Wootson, 2020). The moment echoed his statement that there were "very fine people" on both sides in Charlottesville.

Trump's rhetorical embrace of rightwing fringe groups came just days after large numbers of Proud Boys massed in Portland, Ore., where ongoing racial justice protests have repeatedly descended into violence. Some in the group took to social media to welcome Trump's comments as a call to arms. On Parler, the platform and social network where numerous extremist groups have moved following crackdowns on Facebook on Twitter, the chairman of the Proud Boys, Enrique Tarrio, responded to Trump's remarks by posting, "That's my president!" Numerous effusive posts followed. "Standing by sir," he wrote. Another message soon followed: "So Proud of my guys right now." Members of the group used Trump's "stand back and stand by" comments to create a fresh logo on social media. In an interview, Tarrio said he supported Trump's commentary, a sign that the group's attempts to achieve legitimacy and recognition got a boost during the debate. (Olorunnipa \& Wootson, 2020).

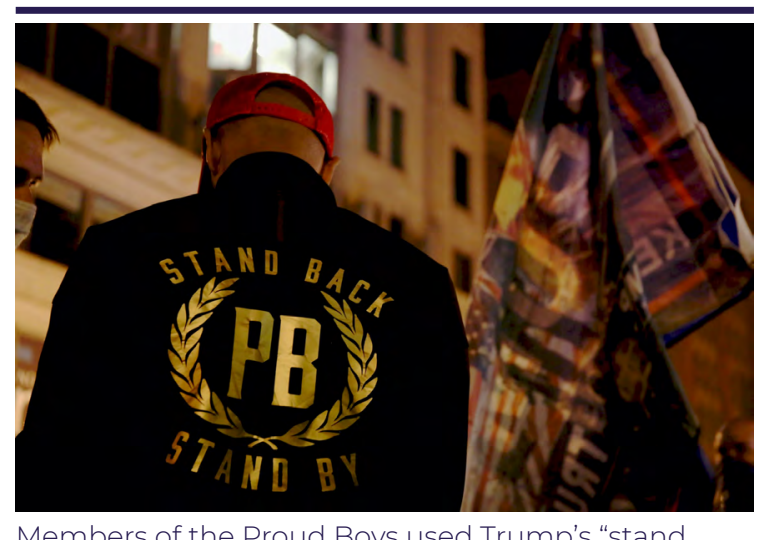

Members of the Proud Boys used Trump's "stand back and stand by" comments to create a fresh logo

The New York Times reported that within minutes of this statement, the Proud Boys' chairman Tarrio called the T-shirt business he owns in Miami to order shirts emblazoned with the logo "Proud Boys standing by." Google searches for the group spiked, and hundreds joined Proud Boys groups on the instant messaging platform Telegram. "I think he was saying I appreciate you and I appreciate your support," said the group's founder, Mclnnes (McBain, 2020). Tarrio also said he interpreted "stand back and stand by" as meaning they should just keep doing 
what they're doing (Murphy, 2020). Tarrio stated in a tweet that he was "extremely proud" of Trump, and that "stand back and stand by" is what the Proud Boys have "always" done (Coaston, 2018).

By telling the Proud Boys to "stand by" and refusing to uniformly denounce the 2017 Unite the Right rally in Charlottesville, Trump has cultivated a favourable ambiguity around the status of militant far-right groups in the political arena (Matanock \& Staniland, 2020). Experts in extremism agreed that Trump's comments amounted to an unprecedented shout-out to a group that has a demonstrated history of fomenting violence in America. "You're essentially telling a paramilitary force to 'stand by'," said Heidi Beirich, an expert on far-right politics who co-founded the Global Project Against Hate and Extremism (Hawkins, 2021).

Therefore, the January 6, 2021 assault on the Capitol was a fitting end to Trump's presidency. It was the logical culmination of four years of violently partisan rhetoric. Trump is less the cause but rather the natural expression of far-right populism run amok. Still, he is an impressive expression of American populism. As the only representative elected by all Americans, the US president has both institutional and rhetorical power given his unique media exposure. The "commander-in-chief" is also the "storyteller-in-chief." His January 6 "Save America" speech is a perfect illustration of the way a populist narrative can sway the masses (Viala-Gaudefroy, 2021).

After the presidential election in 2020 , the Proud Boys had declared its undying loyalty to President Trump. In a November 8, 2020 post in a private channel of the messaging app Telegram, the group urged its followers to attend protests against an election that it said had been fraudulently stolen from Trump. "Hail Emperor Trump," the Proud Boys wrote.

However, as Trump departed the White House, the Proud Boys have also started abandoning his side. In dozens of conversations on social media sites like Gab and Telegram, members of the group have begun calling Trump a "shill" and "extraordinarily weak." They have also urged supporters to stop attending rallies and protests held for Trump or the Republican Party. The discontent with Trump, who condemned the violence, has boiled over. On social media, Proud Boys participants have complained about his willingness to leave office and said his disavowal of the Capitol rampage was an act of betrayal. And Trump, cut off on Facebook and Twitter, has been unable to talk directly to them to soothe their concerns or issue new rallying cries (Frenkel, 2021).

The change in support happened slowly. After the election, the Proud Boys urged their members to attend "Stop the Steal" rallies. One Nov. 23 message on a Proud Boys Telegram page read, "No Trump, no peace." But when Trump's legal efforts failed, the Proud Boys called for him to use his presidential powers to stay in office. In the last two weeks of December, they pushed Trump in their protests and on social media to "Cross the Rubicon." The group expected Trump to champion the mob; instead, Trump released a video on Jan. 8 denouncing the violence. The disappointment was immediately palpable. Since then, at least five men who identified as members of the Proud Boys have been arrested in connection to the Capitol riots. Some Proud Boys became furious that Trump did not appear interested in issuing presidential pardons for their members who were arrested. They accused Trump of "instigating" the events at the Capitol, then "wash[ing] his hands of it" (Frenkel, 2021). 


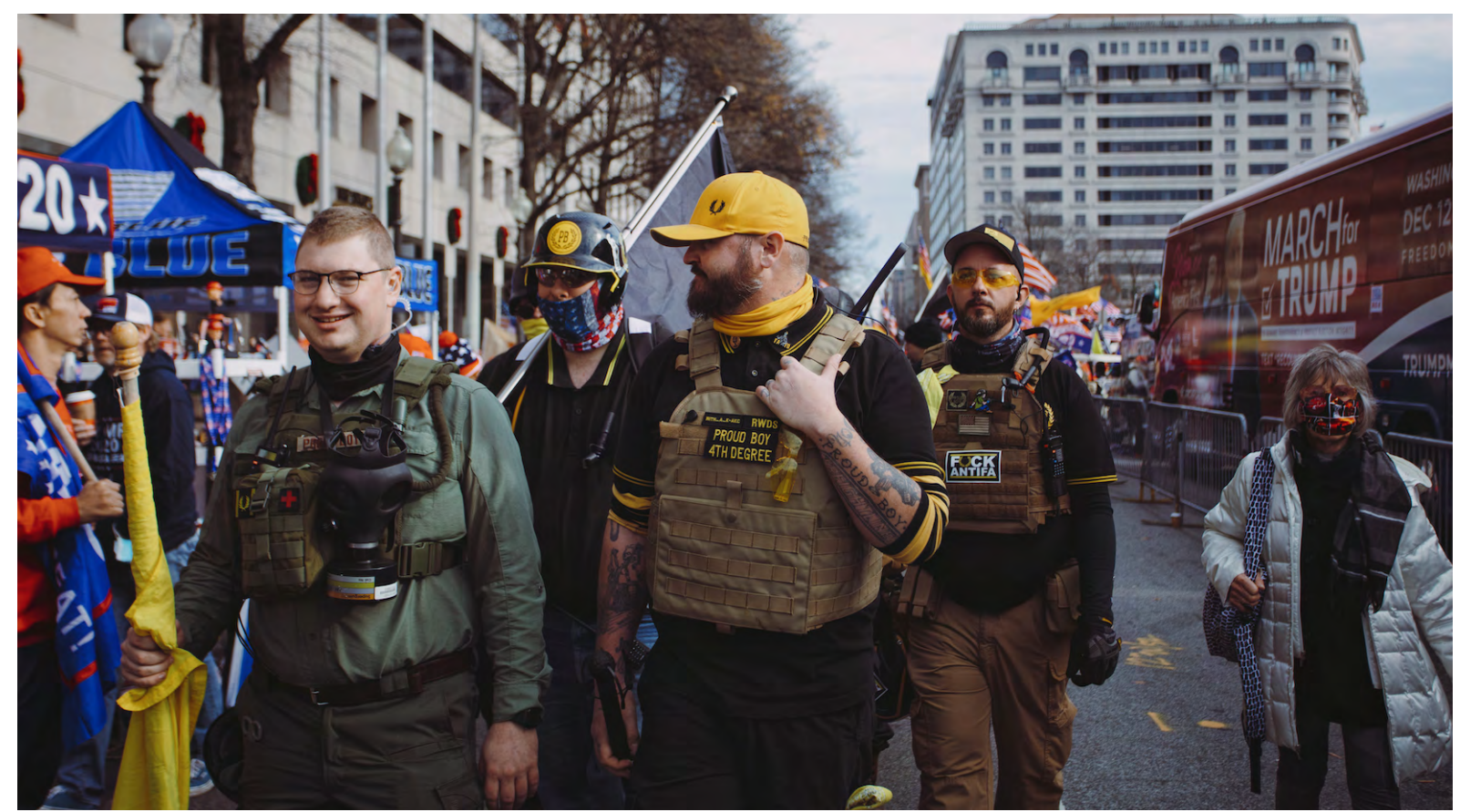

A fourth level member of the Proud Boys during Million Maga March in Washington DC on December 12, 2020.

\section{Violence as a Found- ing Ideology}

As like all other far-right populist groups, the Proud Boys strengthen members' commitment to their perceived in-group, a phenomenon fundamental to demagoguery's "us" versus "them" logic (Vitolo-Haddad, 2019). Furthermore, they adhere to an ideology that consists of both symbolic and physical violence (DeCook, 2018). The Proud Boys' violent characteristics come from their founding mentality. In April 2016, McInnes, who believes violence is "a really effective way to solve problems," said: "I want violence, I want punching in the face. I'm disappointed in Trump supporters for not punching enough," (WNYC-The Takeaway, 2018;

Marantz, 2017a). In August 2017, he further stated that "[W]e don't start fights [...] but we will finish them," (Moser, 2017).

Violence is not confined to official Proud Boys' events; rather, it is a core organizational principle. In a June 2016 episode of The Gavin Mclnnes Show, Mclnnes declared, "We will kill you. That's the Proud Boys in a nutshell. ... We will assassinate you". Mclnnes offers the assertion that political problems, which take on feminine embodiments, are best solved by violence: "Fighting solves everything. We need more violence from the Trump people. Trump supporters: choke a motherfucker. Choke a bitch. Choke a tranny. Get your fingers around the windpipe. If they spit on you, that's assault" (Vitolo-Haddad, 2019). McInnes even made a video praising the use of violence, saying, "What's the matter with fighting? Fighting solves everything. The war on fighting is the same as the war on masculinity." Since the Proud Boys glorifies violence, the SPLC has called the group an "alt-right fight club" (Morlin, 2017).

Mclnnes believes the violence is a logical response to how the "left" has responded to right-wing speaking events, writing in June 2017: “The right isn't violent. The left is. By allowing these sociopaths to shut down free speech with violence you are all but demanding a war. Okay, fine, you got it. It's official. This is a war," (Coaston, 2018). Violence is firmly entrenched in the Proud Boys dogma and venerated within the organization. In early 2017, the group added a new degree to their membership hierarchy: in order to enter the 4th level, a member needs to "get involved in a major fight for the cause." "You get beat up, kick the crap out of an Antifa," McInnes explained (Metro US, 2017.) 
Mclnnes has also claimed in a video message hosted by Rebel Media that Proud Boys "are the only ones fighting" the anti-fascist collective Antifa. "I want you to fight them too," he continued. "It's fun. When they go low, go lower. Mace them back, throw bricks at their head. Destroy them. We've been doing it a while now and I've got to say, it's really invigorating," (McBain, 2020). Mclnnes was filmed punching a counter-protestor outside of the DeploraBall, an unofficial inaugural ball, in Washington DC, in January 2017. Moreover, after a speaking engagement at New York University turned violent, he wryly declared: "I cannot recommend violence enough. It's a really effective way to solve problems." Though he claimed in the interview he was ready to "get violent and beat the f-k out of everybody," he later backtracked in a Proud Boys Magazine piece, assuring the public the fraternal group was opposed to "senseless violence." "We don't start fights, we finish them," Mclnnes wrote (Southern Poverty Law Center, 2021).

According to Kurtner (2020), the Proud Boys justify violence behind this outwardly apolitical motto, "We don't start fights, but we finish them." The Proud Boys' violence is a manifestation of the group's underlying political motivations. To explain why some Proud Boys increase their commitment to violence, it is important to understand the grievances that make involvement appealing to new recruits (Kutner, 2020). For all the digital chaos wrought by the so-called "alt-right," openair political violence remains the most immediate way to radicalise and recruit young men into far-right movements. Videos and gifs of Proud Boys beating up Antifa, in turn, become digital propaganda (O'Connor, 2021).

In a May 2018 episode of Get Off My Lawn, entitled "Fighting Solves Everything," McInnes explains, "You're not a man until you've had the crap beaten out of you, beaten the crap out of someone, had your heart broken, and broken a heart." Under this cultural mode of masculine reproduction, violence is a rule of manhood. Violence becomes not only a condition of manhood but also a conflict resolution strategy and method for survival in a competitive economic system
(Vitolo-Haddad, 2019). "Being bullied is just as important as bullying because they teach you the inevitable truth that we live in a kill or be killed society," Mclnnes once said (McInnes, 2013).

Proud Boys leadership released a "clarified" set of bylaws that seemed to contradict their prior, violent rhetoric: "Any requirement that a brother commit a violent or illegal act as a condition precedent to receiving a fourth degree is, by this bylaw, abolished" (ADL, 2021). Despite this change, and despite Mclnnes leaving the group, his inspiration remains visible, particularly in the violence the Proud Boys still embrace. The Proud Boys often rely on the actions of their opposition to draw attention to themselves and their cause (Coaston, 2018). They are motivated by their shared identification in a symbolic struggle against an imagined "other." In the Proud Boys' case, a rearticulation of the epic struggle between East and West is a fight between good and evil that spilled first blood in the Crusades. Through this mythos, members find redemptive joy through the glorified violence of an illusory war that has become increasingly materialized as reality (Vitolo-Haddad, 2019).

Their organizing is underwritten by a clear sense of urgency, a self-described militant desperation heard in their assertion, "We have one last chance to make the West great again" (Proud Boy Magazine, 2018). Making the most of this "last chance," the Proud Boys unveiled their "official military arm," the Fraternal Order of the Alt-Knights (FOAK), in April 2017. The announcement formalized the paramilitary structure the fraternity had been using, organizing "watchdogs into a force to protect and serve when the police are told to stand down" (Bazile, 2017). The AltKnights were quickly folded back into the main organization, such that any Proud Boy may perceive their actions as extensions of state authority to maintain order when the police are restrained by civil rights ordinances or First Amendment protections (Vitolo-Haddad, 2019).

FOAK was established by Kyle Chapman (a.k.a. Based Stickman) who is a violent felon and who has repeatedly encouraged violence against anti-fascist activists. His 
persona stems from his history of threatening counter-protestors with a heavy iron stick (ADL, 2021), reportedly with Mclnnes's backing. Chapman openly encourages fellow Proud Boys and others on the far right to "sacrifice" for their beliefs. "You are also going to have to come to the realization that you may have to bleed to keep this going," he told a crowd in Sacramento. "You're maybe going to have to do some time in jail and you very may well have to die... I'm willing to die. Are you guys willing to die?" he asked, and was met with cheers (SPLC, 2021).

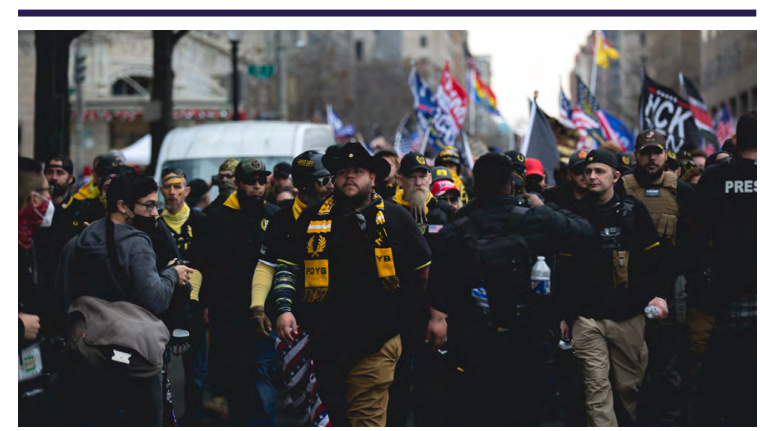

Proud Boys are seen during the Million Maga March in Washington DC on Dec 12, 2020.

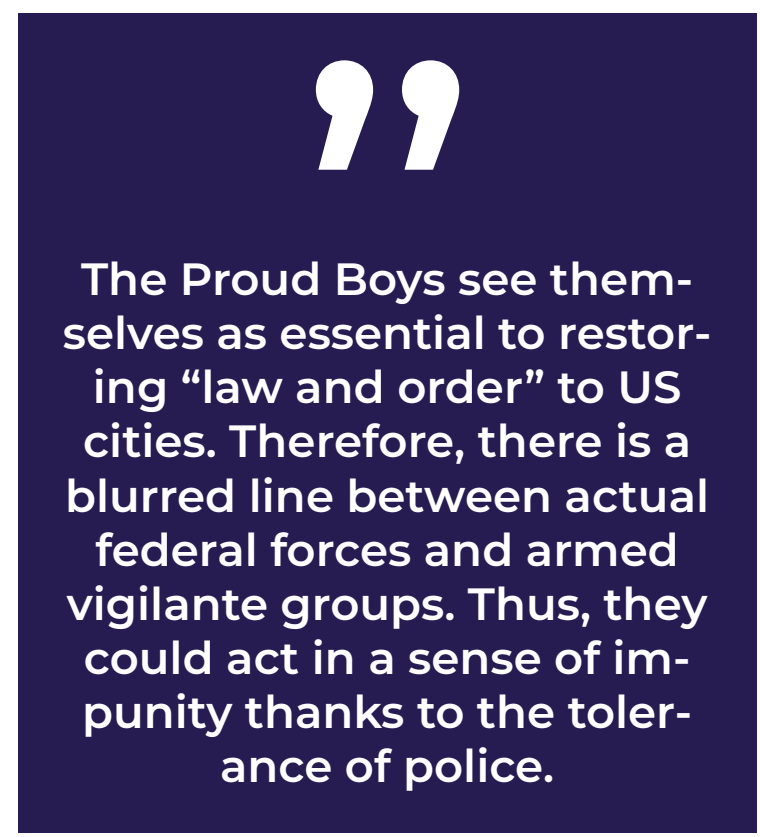

Similar calls have come from Augustus Invictus (Austin Gillespie), a former Florida attorney and Senate candidate. Chapman named him second-in-command of FOAK. Invictus' ideology is a bizarre mix: he holds many mainstream libertarian beliefs but also claims Nazi and antisemitic thinkers as his chief intellectual influencers and paganism as his faith. During his Senate run in 2016, journalists discovered that Invictus had slaughtered a goat and drank its blood as part of a pagan ritual. In campaign material, he criticized the federal government for abandoning eugenics programs. He's also an admitted Holocaust denier (Southern Poverty Law Center, 2021).

The Proud Boys see themselves as essential to restoring "law and order" to US cities. "There's now a blurred line between actual federal forces and armed vigilante groups," said Joseph Lowndes (McBain, 2020), a political scientist at the University of Oregon. Therefore, they could act in a sense of impunity thanks to the tolerance of police. On Aug. 22, 2020, during a Proud Boys march in Portland, members of the organization clashed with Antifa supporters and other counter protesters in front of police headquarters (Hawkins, 2021). This clash between right-wing and left-wing activists was one of many in Portland and other American cities throughout the summer. This is part of a trend of far-right vigilantism, where Proud Boys self-deputize in order to "assist" law enforcement. This logic, however, elides the fact that many members of the group have criminal records for violent behaviour and the organization actively pursues violence against its perceived enemies (ADL, 2021).

Homegrown far-right extremism poses a persistent and lethal threat to the lives and well-being of Americans. This risk is often underestimated because of the devastating impact of the 9/11 terrorist attacks. Excluding 9/11, between 1990 and 2019, the ECDB identified 47 events in the US motivated by Islamist extremism that killed 154 people. When you include $9 / 11$ as a singular event, those numbers jump dramatically to 48 homicide events and 3,150 people killed. The database also identified 217 homicide events motivated by far-right extremism, with 345 killed. And when you include the Oklahoma City bombing, it rises to 218 homicide events and 513 killed. To focus solely on Islamist extremism is to ignore the number of murders perpetrated by the extreme far-right. Evidence shows far-right violent extremism poses a particular threat to law enforcement and racial, ethnic, religious and other minorities (Gruenewald et al., 
2020).

The Proud Boys' commitment ranges from passive online consumption to overt offline action. A 2017 incident in Islamberg - a small Muslim town in upstate New York - provides insight into how some Proud Boys moved from passive consumers of in-group content to active, operational agents (Kutner, 2020). Two years prior, Islamberg had been targeted when former congressional candidate Robert Doggart was arrested by the FBI for a plot to bomb the same community. In a statement later released, Doggart said, "I don't want to have to kill children, but there's always collateral damage" (Ghianni, 2017).

In their online statements, Proud Boys have claimed they have only used violence in self-defence: "If our mere presence causes people to want to commit acts of violence, we're not afraid to defend ourselves," Tarrio said. But members are often seen carrying firearms and bats and donning protective gear, and some have been convicted of crimes against anti-fascist protesters (Murphy, 2020). Members have supported the Proud Boys' agenda by attending and organizing right-wing events (Kramer, 2017). Many regularly appear in their half-serious "uniform": black and gold Fred Perry polo shirts branded with the Proud Boys logo, khaki pants, and red Make America Great Again hats (Vitolo-Haddad, 2019).

Meanwhile, Canada has formally labeled the Proud Boys as a terrorist group. The Proud Boys were recognised as a "terrorist entity," meaning the government may seize property and other belongings connected to the group and financial institutions "are subject to reporting requirements" with respect to the group's property under Canada's Anti-Terrorism Act (Li, 2021). "The Proud Boys consists of semi-autonomous chapters located in the US, Canada, and internationally," Public Safety Canada said in a statement. "The group and its members have openly encouraged, planned, and conducted violent activities against those they perceive to be opposed to their ideology and political beliefs," (Public Safety Canada, 2021).

The Proud Boys has become a fixture at political demonstrations around the country (Hawkins, 2021). Especially in densely populated cities, the Proud Boys exemplify how demagoguery motivates individuals to engage in warlike militancy. This militancy operates under a political framework obfuscated by the smoke and mirrors of capitalism, wherein demagoguery weaponizes feelings of precarity against scapegoated out-groups (Vitolo-Haddad, 2019). Oren Segal, director of the ADL's Center on Extremism, said the Proud Boys hold events purely to attract counter protesters, with the understanding that provoking any counter protesters can feed a "victimization narrative." "So when Antifa throw stuff at them ... Proud Boys are able to say, 'See, they are trying to silence us and stop our freedom of speech,"' he said (Coaston, 2018).

\section{Longing For the Days When Girls Were Girls and Men Were Men}

Members of the Proud Boys are opposed to feminism and promote traditional gender stereotypes in which women are subservient to men (Carter, 2017; WNYCThe Takeaway, 2018). According to the $A D L$, the Proud Boys is misogynistic, and the group calls women "lazy" and "less ambitious" than men while "venerat[ing] the housewife" (Wilson, 2018). The group's founder, McInnes, wrote: "Though sexual intercourse is encouraged, Proud Boys have an endgame, and it is to settle down and have kids. They have absolutely no respect for feminists but venerate the housewife so much, they are actually becoming quite popular with women" (Mclnnes, 2016). He has also called for "enforced monogamy" and criticized feminism as "a cancer" (Wilson, 2018) that "makes women ugly" (ADL, 2021).

The Proud Boys targets men who feel that the modern world is lacking a space for them. The group equates itself with previous "men's" organizations like the Elks Lodge, which were established in a similar response to growing progressive 
trends in society like voting rights being granted to women (Kimmel 2013). In essence, the religious aspect of the movement is merely a call back to a time when white, Christian men were in power - and that position wasn't questioned (DeCook, 2018). Therefore, women are not permitted to be Proud Boys. The group longs for the days when "girls were girls and men were men," (Coaston, 2018; Hawkins, 2021). For Proud Boys, the West is unable to protect the masses, which have been made feminine in their defencelessness and thus desire "to be led by a dominating male." They often assert that only men can understand the struggle of being men and support each other emotionally through the stressors of protecting and defending civilization (Vitolo-Haddad, 2019).

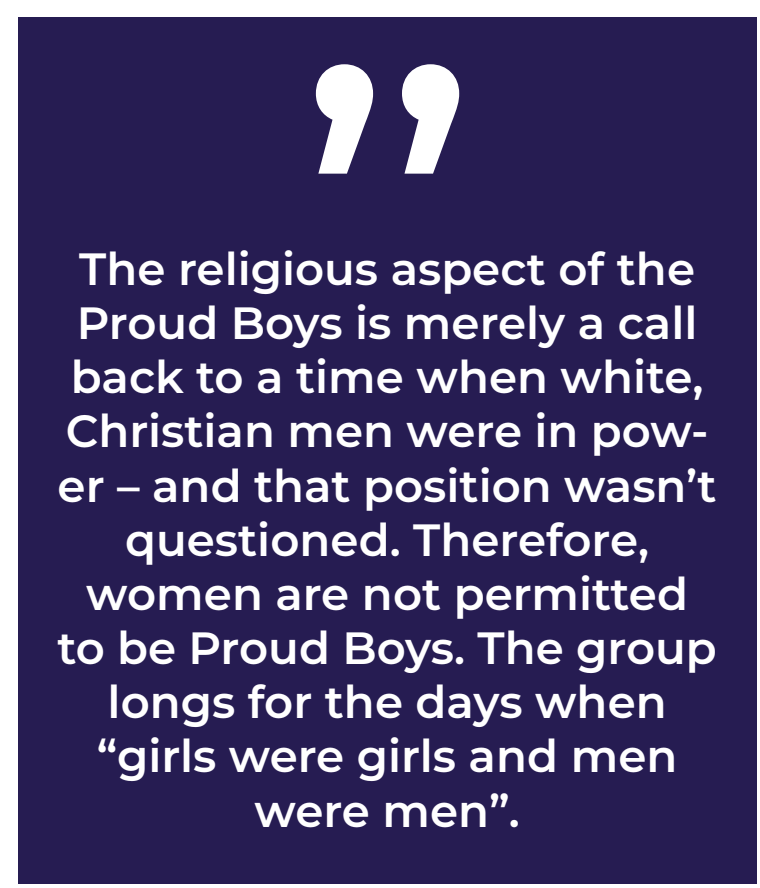

The Proud Boys exist at the intersection of libertarianism, anti-feminism, and misogyny. They obscure their core fascist values by appropriating libertarian philosophy, belying their members' misogyny and desire to control women (Kutner, 2020). Instead of examining neoliberal policies, Proud Boys attribute the changing role of men in the world to women, women who have defied what they believe to be the natural order of things (Michael DeLuca \& Peeples 2002). This desire to return to the "natural" order of things and re-exert control is referred to by members as "radical traditionalism" (Meisenzahl, 2019). Mclnnes says the "victim mentality" of women and other historically op- pressed groups is unhealthy, arguing that "there is an incentive to be a victim. It is cool to be a victim." He sees white men and Western culture as "under siege" and described criticism of his ideas as "victim blaming" (Houpt, 2017). The Proud Boys' activism is largely concerned with decreases in "the life span of white males," men's economic power, and cultural appreciation for "radically traditional men" (Wray, 2017).

The Proud Boys use their anti-masturbation policies to encourage members to seek out women and procreate, hoping to reverse demographic and cultural changes by placing "men and women back in their rightful place, together in a home with children" (Wray, 2017). In the academic space, this is classified more generally as a component of fundamentalism, in which traditional gender roles are enforced (Bosson \& Vandello, 2011). The Proud Boys venerate traditional gender norms and firmly patriarchal social structures; however, the women who become their partners also support and buy-into the ideology (Kelly, 2018). Therefore, the organization has a female-member-only auxiliary wing named "Proud Boys' Girls" that supports the same ideology (Feuer, 2018). One of the key tenets of the Proud Boys is to ultimately settle down and have a family, thus continuing Western civilization; children can be indoctrinated into the ideology (DeCook, 2018).

\section{Within the Proud Boys' Girls - notably,}

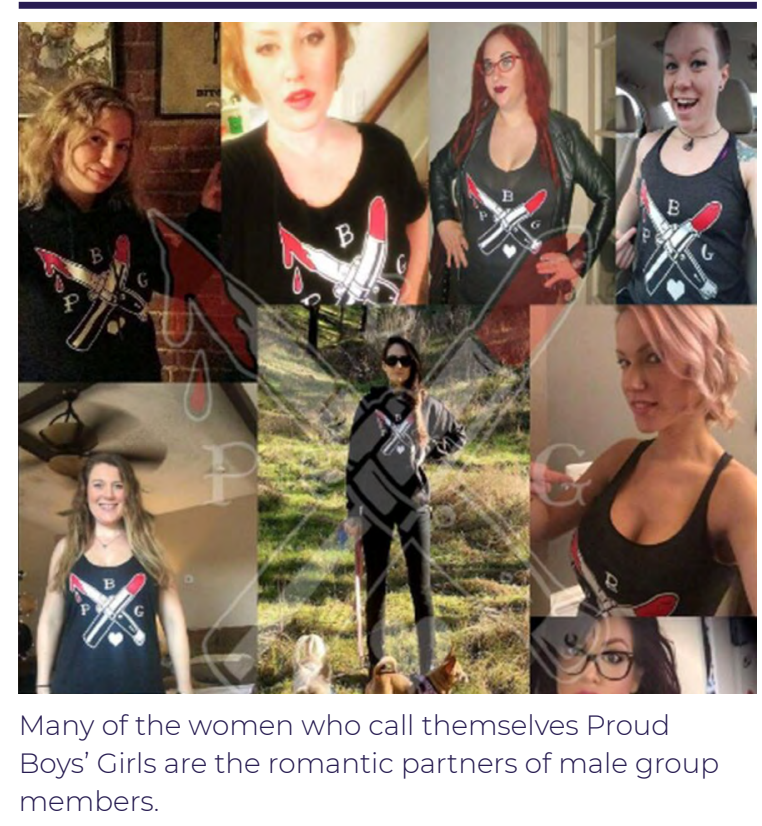


the apostrophe denoting ownership (Bourdieu, 1991) many of the women are the romantic partners of male group members. "I was shocked when I first got the analytics back," says Jack Buckby, the head of Proud Boys UK: "They call themselves Proud Boys" Girls and they are our second-biggest demographic." According to McInnes (2016), it may seem counterintuitive that a male-only group would have such a big female following, but nobody wants men to be men more than the women who depend on them. However, the exclusion of women from the group's meetings is telling of the larger extremist movement that contends that feminism has "infected" Western society. Establishing a separate group for women is are similar to how the Ku Klux Klan had a women's group to support the larger organization (Blee, 2008). These intersections privilege whiteness above all else, as well as men over women, and help to situate the practices of the group, positioning women as mere extensions of men via their role as traditional wives (Kelly, 2018). Thus, the Proud Boys upholds hegemonic patriarchal notions of masculinity and gender roles (DeCook, 2018).

For Proud Boys, the state of the family - as a reproductive mechanism and unit of economic power - is presumed to be reflective of the state of the West (Vitolo-Haddad, 2019). Those who have abdicated their roles as "radically traditional men" are made responsible for declines in nuclear families and economic security, resulting in the inheritance of an "entire pussified, weak, immoral culture of feminized failure" (Wray, 2017). Proud Boy Andrew Bell Ramos explained, "Most of the problems we have in the country are because men aren't stepping up and doing the things they've done forever, being providers, being strong, being manly" (SBS Dateline, 2018). To remedy these masculine failings, Proud Boys call for men to "retake their manhood" and "become a man that great women can love, and great companies can hire" (Wray, 2017).

According to Mclnnes, who no longer supports marriage equality because he believes it's part of a secret plan to destroy Christianity (Coaston, 2018), many Proud Boys were raised by single moms and needed a male figure in their lives (Metro US, 2017). For them, entertaining content acted as the gateway to a new reality constructed of race preservation, conspiracy theories, and male self-awareness through victimhood. These grievances are found in a manosphere, which Mclnnes defines as an ecosystem of disparate male grievance groups that emerged as a reaction to feminism. The manosphere may contain entertaining content, but this content may not always act as a pull factor (Kutner, 2020). Referencing Neo's journey in The Matrix, "taking the red pill" or "getting redpilled" is used to describe an awakening. Getting redpilled refers to the antifeminist ideology within the manosphere. The term taking the red pill refers to men opening their eyes to the reality of male subjugation by women. As a perceived antidote to being seen as effeminate, members maintain their redpilled status through aggressively over-performing masculinity and adopting rigid gender roles (Kutner, 2020).

This fear of being seen as effeminate makes men susceptible to messaging that relies on negative precarity, i.e. Trump evoking the image of America as "weak, vulnerable and effeminate" (Johnson, 2017). Proud Boys don't want freedom in the libertarian sense they have co-opted; they want the freedom to subjugate women in order to invert the redpill paradigm. This makes the Proud Boys authoritarian at their core (Kutner, 2020). The general appeal of groups like the Proud Boys is the retaliation for a perceived loss of white male supremacy and the erosion of privileges that were exclusively for white men (McSwiney, 2021). Trump's hypermasculinity is contrasted to the Democrats' enlightened masculinity, portrayed as weak and feminine. An extreme incarnation of this hypermasculinity is the Proud Boys (Viala-Gaudefroy, 2021).

\section{Proud To Be Islamophobic}

Within the Proud Boys creed "The West is the Best" lies an implicit anti-Eastern bias common among right-wing extremists and white supremacists (ADL, 
2021). According to the SPLC, the group maintains affiliations with extremists and is known for anti-Muslim rhetoric. The group's founder, Gavin Mclnnes, told NBC News (2017), "I'm not a fan of Islam. I think it's fair to call me Islamophobic" (Hawkins, 2021). His Rebel Media videos feature titles like "Donald Trump's Muslim ban is exactly what we need right now," "10 examples of the Koran being violent," and "Islam isn't 'dope.' It's sexist," (SPLC, 2021). Mclnnes' shift to the far-right after he left Vice Media in 2008 also included espousing anti-Muslim sentiments: "the Muslim world is filled with shoeless, toothless, inbred, hill-dwelling, rifle-toting, sodomy-prone men" (Coaston, 2018).

He hosted Pamela Geller, among the most prominent figures in the anti-Muslim movement, on his show "Get Off My Lawn," on the conservative online outlet CRTV. "People in America say 'Muslims are what? One or two percent of the population? There's never going to be sharia law here," he said during the interview before assuring viewers that Britain, where Muslims are "raping children regularly" and where "women are raped several times in one night," is the "canary in the coalmine," (SPLC, 2021). Mclnnes has called the idea of a Muslim-American president "insane" and compared it to electing "a German president in 1942 in America." In a talk show on Fox News, he said there was a "huge problem with inbreeding within the Muslim community," and alleged that "they [Muslims] hate all non-Muslims," (ADL, 2021).

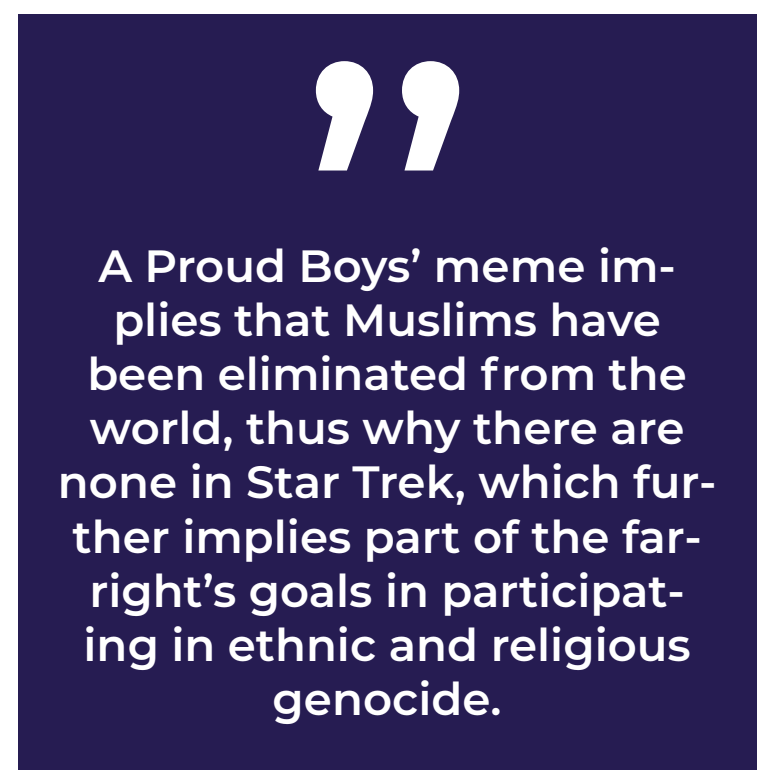

According to an SPLC compilation (2021), Mclnnes has repeatedly used anti-Muslim rhetoric - and has himself said it is fair to call him Islamophobic. "It's such a rape culture with these immigrants, I don't even think these women see it as rape. They see it as just like having teeth pulled," (McInnes, Get Off My Lawn, June 19, 2018). "Muslims have a problem with inbreeding. They tend to marry their first cousins... and that is a major problem here because when you have mentally damaged inbreds - which not all Muslims are, but a disproportionate number are - and you have a hate book called the Koran... you end up with a perfect recipe for mass murder," (Mclnnes, Get Off My Lawn, April 24, 2018)."Muslims are stupid. And the only thing they really respect is violence and being tough" (Mclnnes, The Gavin Mclnnes Show, March 8, 2017).

A Proud Boys' meme implies that Muslims have been eliminated from the world, thus why there are none in Star Trek, which further implies part of the farright's goals in participating in ethnic and religious genocide (DeCook, 2018). This subtlety, the implying rather than outright saying, is typical of dog-whistle politics and rhetoric used by the far-right and other previous fascist governments (Caffier 2017). Moreover, the hashtags used for the images can often be more telling of the ideology than the visual elements of the meme or photograph. For instance, the "\#DeusVult" hashtag comes from a war cry from the Crusades and is invoked to imply that there needs to be another holy war to fight against Islam. (The hashtag may have emerged due to the popularity of a game called Crusader Kings (DeCook, 2018).) Using it symbolically establishes a divide between the "Christian" West and the "Muslim" East, making it a signifier of virulent Islamophobia and modern-day Orientalism (Said, 1979; Ulaby 2017). The members speak of a white, Christian West that they feel has been invaded by immigrants, and echo extremist beliefs that have led to mass killings, such as in the cases of Anders Breivik and Dylann Roof (Teitelbaum, 2015). Remember that new members of the Proud Boys must refuse to apologize for "creating the Western World." 


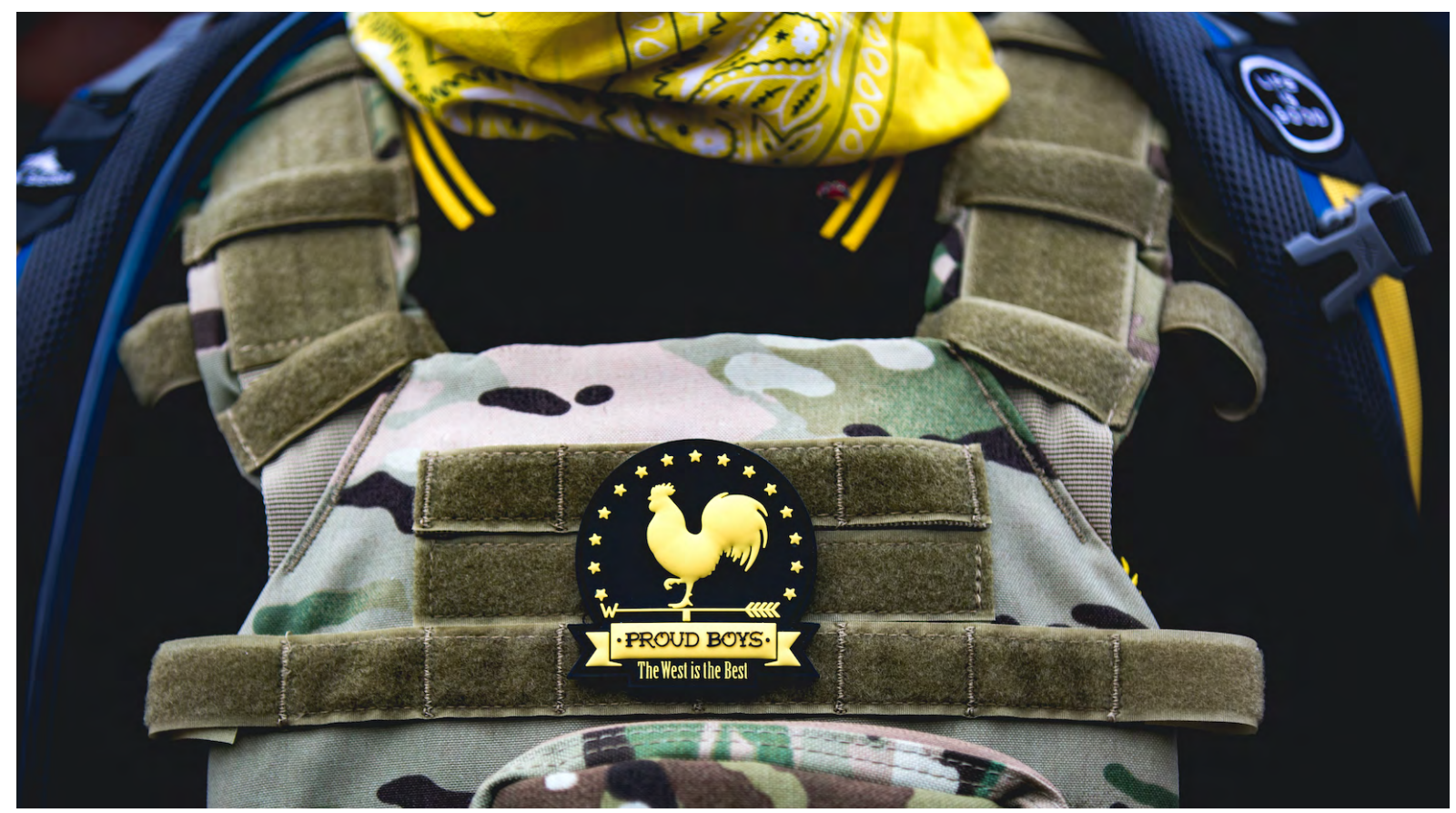

Thee Proud Boys' "The West is The Best" logo.

\section{Antisemitism and the Proud Boys}

Despite the Proud Boys having a chapter in Israel, they are associated with anti-Semites (Israel Faxx, 2020). For instance, Facebook pages for Proud Boys chapters in Florida featured Holocaust denials (like a meme implying the number of those who died during the Holocaust was simply invented) and virulently racist rhetoric (Coaston, 2018). Although Mclnnes has decried antisemitism, his past statements tell a different story. Evidence shows Mclnnes has embraced antisemitism and anti-Israel sentiments, including a video he made for the far-right Canadian outlet Rebel Media initially called "10 Things I Hate about Jews," which was later retitled "Ten Things I Hate About Israel." He has also argued that historically, perhaps Jews "were ostracized for a good reason" (Coaston, 2018). He has also posted videos of himself giving the Nazi salute and repeatedly saying "Heil Hitler" (ADL, 2021).

It was during his trip to Israel in 2017 that Mclnnes appears to have had somewhat of an antisemitic awakening. On his show on March 8, 2017, Mclnnes muses that Jews were somehow responsible for World War II because "the Treaty of Versailles, wasn't that disproportionately influenced by Jewish intellectuals?" He also defended Holocaust deniers and neo-Nazis, saying, "Like at one point, the tour guide goes, "You know, and there are people who think that this didn't happen.' And I felt myself defending the super-farright Nazis, just because I was sick of so much brainwashing. And I felt like going, 'Well, they never said it didn't happen. What they're saying is that it was much less than six million and that they starved to death and they weren't gassed." Then he finished his train of thought with some thoughts about Jews' "obsession" with the Holocaust. "God, they're so obsessed with the Holocaust. I don't know if it's healthy to dwell." At another point McInnes said: "Jews: If you don't want to get people mad, don't be annoying," (ADL, 2021).

Ron Coleman, who is a Jewish lawyer representing McInnes in a defamation lawsuit against the SPLC, said Israelis could be attracted to the Proud Boys because of the value placed on masculinity in Israel. Israeli men, as well as American Jews, may be "nauseated" by what Coleman called "the enforced cultural feminization" of men and boys in the US. Coleman also said Jews who feel left out by the mainstream Jewish political alignment with the left - about 70 percent of 
Jews vote Democratic - may be attracted to the Proud Boys. The Proud Boys have seized upon the presence of an Israeli chapter as evidence that the group is not antisemitic (Israel Faxx, 2020). 


\section{CONCLUSION}

Numerous journalists and experts on far-right extremism have raised the alarm about the Proud Boys and similar racist organisations. However, it wasn't until after the 2020 presidential election - and especially January 6, 2021 extremist insurrection - that the mainstream recognised the threat posed by the far right. Because of this indifference, which led to a deliberate amount of tolerance, white supremacists have accumulated sufficient power to trigger political chaos - chaos that they hope will lead to a race war and the creation of their own white nation (Smith, 2021). Rightfully, many people associate far-right extremism with the rise of Trump. It's true that hate crimes, antisemitism, and the number of hate groups have risen sharply since his campaign began in 2015. But far-right extremists existed long before Trump. While adapting to the times, far-right extremism has continued into the present. It's not dependent on Trump and will remain a threat regardless of his public prominence (Hinton, 2020).

As O'Connor (2021) highlighted, in the face of a belated federal crackdown, the experienced exponents of extremist violence are likely to beat a tactical retreat before making their next push. The movement they fight for now finds itself on new terrain: more organisationally developed than ever before, even with Trump out of office; a fracturing and reforming Republican party creating new alliances and coalitions to leverage and exploit; and the multiplying pressures of the pandemic, the economic crisis, and the climate continuing to build. Trump's inflammatory influence may be long-lasting and yet may yet take a greater toll on American society - after all, the Proud Boys had hoped to assassinate former Vice President Mike Pence and Speaker of the House Nancy Pelosi during their violent storming of the US Capitol (Slisco, 2021). Reports since the insurrection suggest they were closer to their goal than many would like to consider. 


\section{REFERENCES}

- (2016). "Pepe the Frog." Anti-Defamation League (ADL). https://www.adl.org/education/ references/hate-symbols/pepe-the-frog (accessed on January 25, 2021).

- (2017). President Donald Trump's speech in Poland. Youtube. July 6. https://www.youtube.com/watch?v=byBwWvgCDmU (accessed on January 22, 2021).

- (2017). "Gavin McInnes Explains What a Proud Boy Is and Why Porn and Wanking Are Bad." Metro US. February 7. https://www.metro.us/gavin-mcinnes-explains-what-a-proudboy-is-and-why-porn-and-wanking-are-bad/ (accessed on January 22, 2021).

- (2017). "Alternative Right." Southern Poverty Law Center. https://www.splcenter.org/fighting-hate/extremist-files/ideology/alternative-right (accessed on January 23, 2021).

- (2017). "The America First Fraternity Pledges Trump." NBC News. November 2, 2017. https://www.nbcnews.com/leftfield/video/the-america-first-fraternity-pledges-trump-1086714435900 (accessed on January 19, 2021).)

- (2018). "Gavin McInnes and the Proud Boys: Misogyny, Authoritarianism, and the Rise of Multiracial White Supremacy." WNYC The Takeaway. October 16, 2018. https://www.wnycstudios.org/podcasts/takeaway/segments/gavin-mcinnes-and-proud-boys-misogyny-authoritarianism-and-rise-multiracial-white-supremacy (accessed on January 27, 2021).

- (2018). "Far-right group Proud Boys banned from Facebook, Instagram." CBC. October 31, 2018. https://www.cbc.ca/news/canada/proud-boys-facebook-instagram-1.4886514 (accessed on January 23, 2021).

— (2018). Proud Boy Magazine. "Home." Facebook. July 17.

— (2018). "Defending Gender Part 1—Proud Boys." SBS Dateline. YouTube. July 6.

- (2019). "In a Politically Polarized Era, Sharp Divides in Both Partisan Coalitions" Pew Research Center. https://www.people-press.org/2019/12/17/views-on-race-and-immigration/ (accessed on January 26, 2021).

- (2020). "There's a Proud Boys Chapter in Israel." Israel Faxx. Electronic World Communications, Inc.

- (2020). "Here's What You Need to Know About the Proud Boys." Mom Demand Action. September 30, 2020. https://momsdemandaction.org/heres-what-you-need-to-knowabout-the-proud-boys/ (accessed on January 21, 2021).

- (2020). "White Supremacists Double Down on Propaganda in 2019." ADL. February 11, 2020. https://www.adl.org/blog/white-supremacists-double-down-on-propaganda-in-2019 (accessed on January 21, 2021).

- (2021). "Proud Boys." ADL. https://www.adl.org/proudboys (accessed on January 22, 2021).

— (2021). "Proud Boys." Southern Poverty Law Center (SPLC). https://www.splcenter.org/ fighting-hate/extremist-files/group/proud-boys (accessed on January 19, 2021).

- (2021). Currently listed entities. Public Safety Canada. February 3, 2021. https://www.publicsafety.gc.ca/cnt/ntnl-scrt/cntr-trrrsm/Istd-ntts/crrnt-lstd-ntts-en.aspx\#510 (accessed on February 4, 2021). 
Armstrong, Annie. (2017). "Ex-neo Nazis Explain What's Driving the Alt-right." Vice. February 17. https://www.vice.com/en/article/bmpn7q/ex-neo-nazis-explain-whats-driving-the-altright (accessed on January 23, 2021).

Barnes, Luke. (2017). "Proud Boys Founder Disavows Violence At Charlottesville But One Of Its Members Organized The Event." Think Progress. August 24, 2017. https://archive.thinkprogress.org/proud-boys-founder-tries-and-fails-to-distance-itself-from-charlottesville6862fb8b3ae9/ (accessed on January 22, 2021).

Bazile, Pawl. (2017). "The Kids Are Alt-Knights." Proud Boy Magazine. April 24.

Blee, K. M. (2008). Women of the Klan: Racism and Gender in the 1920s. Berkeley, CA: University of California Press.

Bosson, Jenniffer K. \& Vandello, Joseph A.. (2011). "Precarious Manhood and Its Links to Action and Aggression."Current Directions in Psychological Science : a Journal of the American Psychological Society. 20(2), 82-86. https://doi.org/10.1177/0963721411402669

Bourdieu, P. (1991). Language and Symbolic Power. 7th ed. Cambridge, MA: Harvard University Press.

Brittain, Amy \& Willman, David. (2021). "Proud Boys, other fringe groups find refuge - and money - on Christian fundraising website." Washington Post. January 18, 2021. https://www. washingtonpost.com/investigations/a-place-to-fund-hope-how-proud-boys-and-otherfringe-groups-found-refuge-on-a-christian-fundraising-website/2021/01/18/14a536ee-574b-11eb-a08b-f1381ef3d207_story.html (accessed on January 25, 2021).

Caffier, Justin. (2017). "Get to Know the Memes of the Alt-right and Never Miss a Dog-whistle Again." Vice. January 25. https://www.vice.com/en_us/article/ezagwm/get-to-know-thememes-of-the-alt-right-and-never-miss-a-dog-whistle-again (accessed on January 25, 2021).

Carter, Mike. (2017). "Seattle police wary of May Day violence between pro- and anti-Trump groups." Seattle Times. May 1, 2017. https://www.seattletimes.com/seattle-news/crime/seattle-police-wary-of-may-day-violence-between-pro-and-anti-trump-groups/ (accessed on January 28, 2021).

Clark, Simon. (2020). "How White Supremacy Returned to Mainstream Politics." Center for Amarican Progress. July 1, 2020. https://www.americanprogress.org/issues/security/ reports/2020/07/01/482414/white-supremacy-returned-mainstream-politics/ (accessed on January 21,2021$)$.

Crawford, Blyth. (2020). "Coronavirus and conspiracies: how the far right is exploiting the pandemic." The Conversation. September 15, 2020. https://theconversation.com/coronavirus-and-conspiracies-how-the-far-right-is-exploiting-the-pandemic-145968 (accessed on January 20, 2021).

Coaston, Jane. (2018). "The Proud Boys, explained." Vox. October 1, 2020. https://www.vox. com/2018/10/15/17978358/proud-boys-trump-biden-debate-violence (accessed on January 21, 2021).

Cooter, Amy. (2021). "Armed groups from Capitol riot pose longer-term threat to Biden presidency." The Conversation.January 19, 2021. https://theconversation.com/armedgroups-from-capitol-riot-pose-longer-term-threat-to-biden-presidency-153580 (accessed on January 20, 2021).

Crowell, Maddy and O'Regan, Sylvia Varnham. (2019). "Extremist cops: how US law enforcement is failing to police itself." The Guardian. December 13, 2019. 
https://www.theguardian.com/us-news/2019/dec/13/how-us-law-enforcement-is-failingto-police-itself?utm_term=fbb08628b4cd413f5c3d64010ac0a90a\&utm_campaign=TheLongRead\&utm_source=esp\&utm_medium=Email\&CMP=longread_email (accessed on January 18, 2021).

Crusius, Patrick. (2019). “The Inconvenient Truth.” Manifesto. August 3, 2019.

Culkin, Robert. "Who Are The Proud Boys?" Proud Boy Magazine. August 24, 2017.

Dickson, Ej. (2021). "Proud Boys Channels Are Exploding on Telegram." Rolling Stone. January 14, 2021. https://www.rollingstone.com/culture/culture-news/proud-boys-telegram-farright-extremists-1114201/ (accessed on January 20, 2021).

Durham, Martin. (1996). "Preparing for Armageddon: Citizen Militias, the Patriot Movement and the Oklahoma City Bombing." Terrorism and Political Violence. 8.1: 65-79.

DeCook, Julia R. (2018). "Memes and symbolic violence: \#proudboys and the use of memes for propaganda and the construction of collective identity." Learning, Media and Technology. 43(4), 485-504. https://doi.org/10.1080/17439884.2018.1544149

Elders, The. (2018). "Top 20 Myths About The Proud Boys." Proud Boy Magazine. December 2.

Feuer, Alan. (2018). "Proud Boys Founder: How He Went From Brooklyn Hipster to Far-Right Provocateur." The New York Times. October 16, 2018. https://www.nytimes. com/2018/10/16/nyregion/proud-boys-gavin-mcinnes.html (accessed on January 28, 2021).

Frenkel, Sheera. (2021). "'A total failure': The Proud Boys now mock Trump." The New York Times. January 20, 2021. https://www.seattletimes.com/nation-world/nation/a-total-failurethe-proud-boys-now-mock-trump/ (accessed on January 21, 2021).

Freund, Ashley. (2013). "I Can Has Voice? A Semiotic Study of Internet Memes and Their Reflection of Culture." Semiotics. 127-139.

Fukuyama, Francis. (2021). "Rotten to the Core? How America's Political Decay Accelerated During the Trump Era." Foreign Affairs. January 18, 2021. https://www.foreignaffairs.com/articles/united-states/2021-01-18/rotten-core (accessed on January 19, 2021).

Gabbatt, Adam. (2017). "'Jews will not replace us': Vice film lays bare horror of Neo-Nazis in America," The Guardian. August 16, 2017. https://www.theguardian.com/us-news/2017/ aug/16/charlottesville-neo-nazis-vice-news-hbo (accessed on January 26, 2021).

Gabbatt, Adam. (2020). "Wave of extremist Republicans run for office, many with Trump's blessing." The Guardian. August 24, 2020. https://www.theguardian.com/us-news/2020/ aug/24/wave-rightwing-republicans-run-office-trump-blessing-extremist (accessed on January 21, 2021).

Ghianni, Tim. (2017). "Tennessee Man Sentenced Over Plot To Attack Muslim Community." Reuters. June 15. https://www.reuters.com/article/us-tennessee-muslim-crime/tennessee-man-sentenced-over-plot-to-attack-muslim-community-idUSKBN1962R7 (accessed on January 22, 2021).

Glaser, April. (2019). "The Swag Shop of the Far Right." Slate. February 7, 2019. https://slate. com/technology/2019/02/proud-boys-1776-shop-paypal-square-chase-removed.html (accessed on January 23, 2021).

Goldzwig, Steven R.. (1989). "A Social Movement Perspective on Demagoguery: Achieving Symbolic Realignment."Communication Studies. 40.3: 202-28. 
Greenspan, Rachel E. (2020). "What to know about the Proud Boys, the extremist group that Trump name-checked during the first presidential debate." Insider. September 30, 2020. https://www.insider.com/proud-boys-trump-debate-who-what-comments-hategroup-2020-9 (accessed on January 23, 2021).

Greig, Finlay. (2021). "Who are Proud Boys? The 'Western chauvinist' far-right group explained - and what Donald Trump has previously said about them." The Scotsman. January 12, 2021. https://www.scotsman.com/news/world/who-are-proud-boys-westernchauvinist-far-right-group-explained-and-what-donald-trump-has-previously-said-aboutthem-2988105 (accessed on January 21, 2021).

Grigoriadis, Vanessa. (2003). "The Edge of Hip: Vice, the Brandh." The New York Times. September 28, 2003. https://www.nytimes.com/2003/09/28/style/the-edge-of-hip-vice-thebrand.html (accessed on January 21, 2021).

Gruenewald, Jeff; Freilich, Joshua D.; Chermak, Steven \& Parkin, William. (2020). "19 years after 9/11, Americans continue to fear foreign extremists and underplay the dangers of domestic terrorism." The Conversation. September 10, 2020. https://theconversation.com/19years-after-9-11-americans-continue-to-fear-foreign-extremists-and-underplay-the-dangers-of-domestic-terrorism-145914 (accessed on January 20, 2021).

Hatmaker, Taylor. (2018). "Facebook is the Recruiting Tool of Choice for Far-right Group the Proud Boys." Tech Crunch. August 11, 2018. https://techcrunch.com/2018/08/10/ proud-boys-facebook-mcinnes/?guccounter=1 (accessed on January 23, 2021).

Hawkins, Derek. (2021). "Trump's 'stand by' remark puts the Proud Boys in the spotlight." Washington Post. September 30, 2020.

Hinton, Alexander. (2020). "US Capitol mob highlights 5 reasons not to underestimate farright extremists." The Conversation. October 30, 2020. https://theconversation.com/us-capitol-mob-highlights-5-reasons-not-to-underestimate-far-right-extremists-148610 (accessed on January 20,2021 ).

Holan, Angie D. (2019). “In Context: Donald Trump's 'very fine people on both sides' remarks (transcript)," PolitiFact. April 26, 2019. https://www.politifact.com/article/2019/apr/26/ context-trumps-very-fine-people-both-sides-remarks/ (accessed on January 26, 2021).

Houpt, Simon. (2017). "Everything inside Gavin Mclnnes." The Globe and Mail. August 18, 2017. https://www.theglobeandmail.com/arts/television/gavin-mcinnes-path-to-the-farrightfrontier/article36024918/ (accessed on January 22, 2021).

Jacoby, S., and Ochs, E. (1995). "Co-Construction: An Introduction." Research on Language and Social Interaction. 28: 171-183. doi:10.1207/s15327973rlsi2803_1

Johnson, Paul Elliott. (2017). "The Art of Masculine Victimhood: Donald Trump's Demagoguery." Women's Studies in Communication. 40.3: 229-50.

Jones, Seth G.; Doxsee, Catrina \& Harrington, Nicholas. (2020). "The Escalating Terrorism Problem in the United States." CSIS. https://csis-website-prod.s3.amazonaws.com/s3fs-public/publication/200612_Jones_DomesticTerrorism_v6.pdf (accessed on January 21, 2021).

Kaplan, Alex. (2020). "Here are the QAnon supporters running for Congress in 2020." Media Matters for America. September 9, 2020. https://www.mediamatters.org/qanon-conspiracy-theory/here-are-qanon-supporters-running-congress-2020 (accessed on January 21, 2021).

Kelly, Annie. (2018). "The Housewives of White Supremacy." The New York Times. June 1, 2016. https://www.nytimes.com/2018/06/01/opinion/sunday/tradwives-women-alt-right.html 
(accessed on January 25, 2021).

Kimmel, M. (2013). Angry White Men: American Masculinity at the End of an Era. New York: Nation Books.

Kirby, Jen. (2018). "Trump wants fewer immigrants from 'shithole countries' and more from places like Norway." Vox.January 11, 2018. https://www.vox.com/2018/1/11/16880750/ trump-immigrants-shithole-countries-norway (accessed on January 26, 2021).

Kramer, Corey. (2017). "Portland Showdown in Photos." Proud Boy Magazine. August 10.

Kutner, Samantha. (2020). Swiping Right: The Allure of Hyper Masculinity and Cryptofascism for Men Who Join the Proud Boys. International Centre for Counter-Terrorism.

https://www.jstor.org/stable/pdf/resrep25259.pdf (accessed on January 22, 2021).

Li, David K. (2021). "Canada labels far-right Proud Boys a terrorist entity." NBC

News. February 3, 2021. https://www.nbcnews.com/news/us-news/canada-la-

bels-far-right-proud-boys-terrorist-entity-n1256615 (accessed on February 4, 2021).

MacFarquhar, Neil; Feuer, Alan; Baker, Mike; Frenkel, Sheera. (2020). "Far-Right Group That Trades in Political Violence Gets a Boost." The New York Times. September 30, 2020. https:/l www.nytimes.com/2020/09/30/us/proud-boys-trump.html (accessed on January 21, 2021).

Marantz, Andrew. (2017). "The Alt-Right Branding War Has Torn the Movement in Two." The New Yorker. July 6, 2017. https://www.newyorker.com/news/news-desk/the-alt-right-branding-war-has-torn-the-movement-in-two (accessed on January 21, 2021).

Marantz, Andrew. (2017a). "Trump Supporters at the DeploraBall." The New Yorker. January 30, 2017. https://www.newyorker.com/magazine/2017/02/06/trump-supporters-at-the-deploraball (accessed on January 27, 2021).

Matanock, Aila M. \& Staniland, Paul. (2020). "The Militarization of U.S. Politics." Foreign Affairs. October 29, 2020. https://www.foreignaffairs.com/articles/united-states/2020-10-29/ militarization-us-politics (accessed on January 19, 2021).

Mathias, Christopher. (2020). "All The President's Men - Looking back at four years of MAGA terror." The Huffington Post. November, 10, 2020. https://www.huffpost.com/entry/maga-terror-trump-militias_n_5f832f7ec5b62f97bac42a7c (accessed on January 21, 2021).

McAleenan, Kevin. (2019). Strategic Framework for Countering Terrorism and Targeted Violence. Washington, DC: Department of Homeland Security. September 2019. https://www. dhs.gov/sites/default/files/publica-tions/19_0920_plcy_strategic-framework-countering-terrorism-targeted-violence.pdf

McBain, Sophie. (2020). "The rise of the Proud Boys." New Statesman. October 9, 2020. Vol. 149, no. 5541, p. 26.

McInnes, Gavin. (2013). The Death of Cool: From Teenage Rebellion to the Hangover of Adulthood. New York: Scribner.

McInnes, Gavin. (2016). "Introducing: The Proud Boys." Taki's Magazine. September 15. https://www.takimag.com/article/introducing_the_proud_boys_gavin_mcinnes/ (accessed on January 22, 2021).

McSwiney, Jordan. (2021). "Why were the Capitol rioters so angry? Because they're scared of losing grip on their perverse idea of democracy." The Conversation. January 7, 2021. https://theconversation.com/why-were-the-capitol-rioters-so-angry-because-theyrescared-of-losing-grip-on-their-perverse-idea-of-democracy-152812 (accessed on January 
20, 2021).

Meisenzahl, Mary. (2019). "Inside The World Of Weird Catholic Twitter - And The 'Rad Trads' Keeping The OldTraditions Alive." MEL Magazine. https://melmagazine.com/en-us/storyl rad-trad-weird-catholic-twitter (accessed on January 22, 2021).

Michael DeLuca, Kevin; Peeples, Jennifer. (2002). "From public sphere to public screen: democracy, activism, and the 'violence' of Seattle." Critical Studies in Media Communication. 19(2), 125-151. https://doi.org/10.1080/07393180216559

Miller, Cassie. (2018). "McInnes, Molyneux, and 4chan: Investigating pathways to the altright." Southern Poverty Law Center. April 19, 2018. https://www.splcenter.org/20180419/ mcinnes-molyneux-and-4chan-investigating-pathways-alt-right (accessed on January 23, 2021).

Mina, A. X. (2018). Memes to Movements: How the World's Most Viral Media is Changing Social Protest and Power. Boston: Beacon Press.

Morlin, Bill. (2017). "New Alt-Right 'Fight Club' Ready for Street Violence." Southern Poverty Law Center. April 25,2017. https://www.splcenter.org/hatewatch/2017/04/25/new-fight-clubready-street-violence (accessed on January 22, 2021).

Moser, Bob. (2017). "Why the 'Alt-Lite' Celebrated the Las Vegas Massacre." The New Republic. October 6, 2017. https://newrepublic.com/article/145192/alt-lite-celebrated-las-vegas-massacre (accessed on January 27, 2021).

Murphy, Paul P.. (2020). "Trump's debate callout bolsters far-right Proud Boys." CNN. October 1, 2020. https://edition.cnn.com/2020/09/30/politics/proud-boys-trump-debate-trnd/ index.html (accessed on January 21, 2021).

Nagle, Angela. (2016). "The New Man of 4chan." The Baffler. March 2016, No. 30. https://thebaffler.com/salvos/new-man-4chan-nagle (accessed on January 23. 2021).

Nagle, A. (2017). Kill All Normies: Online Culture Wars from 4Chan and Tumblr to Trump and the Alt-right. Alresford: Zero Books.

O'Connor, Brendan. (2021). "Trump's useful thugs: how the Republican party offered a home to the Proud Boys." The Guardian. January 21, 2021. https://www.theguardian.com/ news/2021/jan/21/donald-trump-useful-thugs-proud-boys-far-right-republican-party?utm _ term=cd75c62a9d7668f67c949ce5d85440e0\&utm_campaign=TheLongRead\&utm _ source=esp\&utm_medium=Email\&CMP=longread_email (accessed on January 23, 2021).

Olorunnipa, Toluse \& Wootson, Cleve R. Jr. (2020). "Trump refused to condemn white supremacists and militia members in presidential debate marked by disputes over race." Washington Post. September 29, 2020.

Orth, Michael. (1990) "Reefs on the Right: Fascist Politics in Contemporary American Libertarian Utopias." Extrapolation. 31.4: 293-316.

Ortiz, Jorge L. (2020). "An invasion of propaganda: Experts warn that white supremacist messages are seeping into mainstream." USA Today. February 14, 2020. https://eu.usatoday.com/story/news/nation/2020/02/14/white-supremacy-propaganda-increasing-mainstream-violence/4755150002/ (accessed on January 21, 2021).

Paddock, Troy. R. E. (2015). "Performing Politics." Contemporary Aesthetics. Volume 13. https://quod.lib.umich.edu/c/ca/7523862.0013.014?view=text;rgn=main (accessed on January 23,2021$)$. 
Perry, Todd. (2018). "Here's A List Of Politicians With White Supremacist Ties Currently Running For Congress." Good. February 15, 2018. https://www.good.is/articles/white-supremacists-running-for-office (accessed on January 21, 2021).

Reed, Adolph, Jr. (2013). "Django Unchained, Or, The Help: How 'Cultural Politics' Is Worse Than No Politics at All, and Why." Nonsite.org. February 25, 2013. https://nonsite.org/django-unchained-or-the-help-how-cultural-politics-is-worse-than-no-politics-at-all-and-whyl (accessed on January 22, 2021).

Roettgers, Janko. (2018). "Twitter Shuts Down Accounts of Vice Co-Founder Gavin Mclnnes, Proud Boys Ahead of 'Unite the Right' Rally." Variety. August 10, 2018. https://variety. com/2018/digital/news/twitter-shuts-down-accounts-of-vice-co-founder-gavin-mcinnesproud-boys-ahead-of-unite-the-right-rally-1202902397/ (accessed on January 23, 2021).

Said, E. W. (1979). Orientalism. New York: Vintage.

Sankin, Aaron \& Pham, Scott. (2017). "In Chat Rooms, Unite The Right Organizers Planned To Obscure Their Racism."Reveal News. August 31, 2017. https://www.revealnews.org/article/ in-chat-rooms-unite-the-right-organizers-planned-to-obscure-their-racism/ (accessed on January 22, 2021).

Sargent, Greg. (2020). "A former DHS insider sheds a darker light on Trump's vile 'Proud Boys' comment." Washington Post. September 30, 2020.

Shifman, L. 2014. Memes in Digital Culture. Cambridge, MA: MIT Press.

Sidner, Sara. (2020). "Leader of Proud Boys also leads grassroots group Latinos for Trump." CNN. October 1, 2020. https://edition.cnn.com/2020/10/01/politics/proud-boys-leader-latinosfor-trump/index.html (accessed on January 21, 2021).

Slisco, Aila. (2021). "Proud Boys Intended To Kill Mike Pence and Nancy Pelosi, FBI Witness Says." Newsweek. January 15, 2021. https://www.newsweek.com/proud-boys-intended-killmike-pence-nancy-pelosi-fbi-witness-says-1562062 (accessed on January 21, 2021).

Smith, Shannon M.. (2021). "US Capitol protesters, egged on by Trump, are part of a long history of white supremacists hearing politicians' words as encouragement." The Conversation. January 7, 2021. https://theconversation.com/us-capitol-protesters-egged-on-bytrump-are-part-of-a-long-history-of-white-supremacists-hearing-politicians-words-as-encouragement-152867 (accessed on January 20, 2021).

Solsman, Joan E. (2018). "YouTube bans Proud Boys founder Gavin McInnes, latest tech giant to kick him off." CNET. December 10, 2018. https://www.cnet.com/news/youtubebans-proud-boys-founder-gavin-mcinnes-latest-tech-giant-to-kick-him-off/ (accessed on January 23, 2021).

Sommer, Will. (2017). "The Fratty Proud Boys are the Alt Right's Weirdest New Phenomenon." February 5. https://medium.com/@willsommer/the-fratty-proud-boys-are-the-altrights-weirdest-new- phenomenon-7572b31e50f2 (accessed on January 23, 2021).

Stolberg, Sheryl Gay \& Rosenthal, Brian M. (2017). "Man Charged After White Nationalist Rally In Charlottesville Ends In Deadly Violence." The New York Times. August 12. https:/l www.nytimes.com/2017/08/12/us/charlottesville-protest-white-nationalist.html (accessed on January 22, 2021).

Strickland, Patrick. (2018). "Alarm over white supremacist candidates in US." Al Jazeera. February 9, 2018. https://www.aljazeera.com/news/2018/2/9/alarm-over-white-supremacistcandidates-in-us (accessed on January 21, 2021). 
Tajfel, H. (1978). Differentiation between Social Groups: Studies in the Social Psychology of Intergroup Relations. Vol. XV. Oxford: Academic Press.

Teitelbaum, Benjamin R. (2015). "The New Face of Global White Nationalist Terror." Foreign Policy. June 15, 2015. https://foreignpolicy.com/2015/06/25/the-new-face-of-white-nationalist-terror-dylann-roof-anders-behring-breivik/ (accessed on January 23, 2021).

Trump, Donald J. (2017). "Remarks by President Trump to the People of Poland, Official White House Transcript." White House. July 6, 2017.

Ulaby, Neda. (2017). "Scholars Say White Supremacists Chanting 'Deus Vult' Got History Wrong." NPR. September 4, 2017. https://www.npr.org/2017/09/04/548505783/scholars-saywhite-supremacists-chanting-deus-vult-got-history-wrong (accessed on January 23, 2021).

Vitolo-Haddad, CV. (2019). "The Blood of Patriots: Symbolic Violence and 'The West." Rhetoric Society Quarterly. 49.3: 280-296.

Viala-Gaudefroy, Jérôme. (2021). "How Donald Trump's populist narrative led directly to the assault on the US Capitol." The Conversation. January 13, 2021. https://theconversation. $\mathrm{com} /$ how-donald-trumps-populist-narrative-led-directly-to-the-assault-on-the-us-capitol-153277 (accessed on January 20, 2021).

Walters, Joanna. (2017). "Neo-Nazis, white nationalists, and internet trolls: who's who in the far right." The Guardian.August 17, 2017. https://www.theguardian.com/world/2017/aug/17/ charlottesville-alt-right-neo-nazis-white-nationalists (accessed on January 22, 2021). 


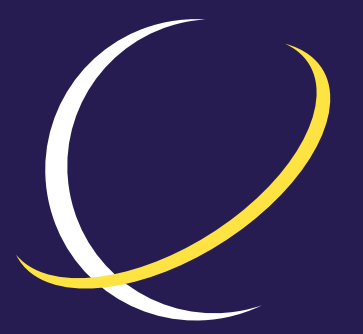

\section{ECPS \\ EUROPEAN CENTER for POPULISM STUDIES}

\section{ABOUT ECPS}

The European Center for Populism Studies (ECPS) is an independent, nonpartisan, nonprofit organization, based in Brussels, for research on and analysis of challenges posed by the resurgence of political populism. ECPS facilitates collaboration among networks of academic experts, practitioners, policymakers, media, and other stakeholders. ECPS offers a platform for the exchange of policy solutions on issues relating to rising populism and provides insights for policy-making and critical analysis to raise broader awareness and engagement through:

\section{Publications}

\section{Academic publications}

Policy reports

White papers

Commentaries

Podcasts and interviews with experts

Events, seminars, workshops, and conferences

\section{Research Programs}

Authoritarianism

Digital Populism

Economics

Environment \& Climate

Extremism \& Radicalisation

\section{Gender}

Human Rights

Foreign Policy

Leadership \& Persona

Migration

\section{ECPS Youth Program}

ECPS Academy 